\title{
Digestion, absorption and utilization of single-cell protein by the preruminant calf
}

\author{
The true digestibility of milk and bacterial protein and the apparent digestibility \\ and utilization of their constituent amino acids
}

\author{
BY CYNTHIA A. SEDGMAN*, J. H. B. ROY, JOANNE THOMAS, \\ I. J. F. STOBO AND P. GANDERTON \\ National Institute for Research in Dairying, Shinfield, Reading RG2 9AT
}

(Received 4 December 1984 - Accepted 28 February 1985)

1. Two experiments of Latin square design were made, each with four Friesian bull calves fitted with re-entrant
duodenal and ileal cannulas at $4-10 \mathrm{~d}$ of age. The calves were used to study the effect of giving milk-substitutes
containing $0,300,500$ and $700 \mathrm{~g}$ bacterial protein (Pruteen) $/ \mathrm{kg}$ total protein on apparent digestibility of nitrogen
fractions and amino acids and true digestibility of ${ }^{3} \mathrm{H}-\mathrm{labelled}$ milk protein and ${ }^{35} \mathrm{~S}-\mathrm{labelled}$ bacterial protein in
the small intestine. A third experiment of Latin square design with four intact Friesian calves was used to measure
apparent digestibility of nutrients throughout the alimentary tract and retention of $\mathrm{N}$, calcium and phosphorus.
2 . At the duodenum, volume of outflow, its $\mathrm{pH}$, and outflow of total- $\mathrm{N}(\mathrm{TN}$ ), protein- $\mathrm{N}$ (PN) and non-protein- $\mathrm{N}$
(NPN) decreased with time after feeding. At the ileum, volume of outflow and TN outflow were unaffected by
time after feeding but PN outflow decreased; NPN outflow at the ileum increased to a maximum $6 \mathrm{~h}$ after feeding and then declined.

3. Increased inclusion of Pruteen did not affect the volume of outflow at the duodenum or ileum, but duodenal PN outflow increased. At the ileum, pH values were lower and TN, PN and NPN outflows were higher with increasing concentration of Pruteen in the diet. Apparent digestibility in the small intestine tended to decrease with greater amounts of Pruteen, but was only significant for NPN. Apparent digestibility from mouth to ileum significantly decreased for TN and PN as Pruteen inclusion increased.

4. Amino acid concentration in duodenal outflow, with the exception of that of arginine, reflected intake. The total amount of each amino acid in ileal outflow increased and the apparent digestibility of most amino acids decreased with greater amounts of Pruteen in the diet. Apparent digestibility of nucleic acid- $\mathrm{N}$ from Pruteen was very high.

5. True digestibility in the small intestine and between mouth and ileum of ${ }^{3} \mathrm{H}$-labelled milk protein was high and did not differ between dietary treatments. True digestibility of ${ }^{35}$ S-labelled Pruteen was low for the milk-protein diet and tended to increase linearly as more dietary Pruteen was included.

6. Dry matter concentration in faeces and a high apparent digestibility throughout the whole alimentary tract of carbohydrates did not differ between treatments. Apparent digestibility of dry matter, organic matter, crude protein and fat, apparent absorption of $\mathrm{Ca}, \mathrm{P}$ and ash throughout the tract, retention of $\mathrm{N}, \mathrm{Ca}$ and $\mathrm{P}$ and biological value of the protein decreased with inclusion rates greater than $300 \mathrm{~g}$ Pruteen $/ \mathrm{kg}$ total dietary protein. The amount of $\mathrm{N}$ apparently absorbed in the large intestine was estimated as $0.9 \mathrm{~g} / \mathrm{d}$.

7. Comparison of intake of apparently absorbed essential amino acids with requirement suggests that histidine is likely to be the limiting amino acid, assuming that arginine is synthesized in the body.

8. Efficiencies of utilization of protein for tissue synthesis and to cover obligatory loss are estimated as $0 \cdot 80$, $0.75,0.66$ and 0.47 for diets containing $0,300,500$ and $700 \mathrm{~g}$ Pruteen $/ \mathrm{kg}$ total protein in the diet. Efficiencies of utilization of individual essential amino acids were also estimated.

The effect on abomasal outflow and composition of varying the inclusion rate of bacterial protein (Pruteen; ICI Ltd, Billingham) in milk-substitute diets for calves was reported by Sedgman et al. (1985). Further experiments to measure the absorption of amino acids from Pruteen in the small intestine and their subsequent utilization, and to determine the true digestibility of ${ }^{3} \mathrm{H}$-labelled milk protein and ${ }^{35} \mathrm{~S}$-labelled Pruteen protein are now presented. Digestibility and balance trials were also made on intact calves of the same live weight and given the same amount of diet. The detailed results of these experiments have appeared in Sedgman (1980).

* Present address: Lilly Research Centre Ltd, Erl Wood Manor, Windlesham, Surrey GU20 6PH. 


\section{METHODS}

Calves

Four Friesian bull calves obtained within $24 \mathrm{~h}$ of birth from the Institute's herd were used to study the apparent absorption of nitrogen compounds, including amino acids (Expt 1 (a)), and three further calves to determine the apparent absorption of $\mathrm{N}$ compounds and the true digestibility of milk protein and Pruteen (Expt 1(b)), with one calf common to both experiments. Four additional calves were used in the digestibility and balance trials in Expt 2.

Each calf was given $7 \mathrm{~kg}$ colostrum, obtained from the first two milkings after parturition from Friesian cows, in the first four feeds of life. After the colostrum-feeding period, the calves were given diet L, a milk-substitute diet based on skim-milk powder (Sedgman $e t$ al. 1985), until they were allocated their first experimental diet. All calves were given liquid diets from a bucket, the diets being reconstituted at $143 \mathrm{~g}$ powder $/ \mathrm{kg}$ liquid.

The seven calves for Expt 1 were prepared with duodenal and ileal re-entrant cannulas between 4 and $10 \mathrm{~d}$ of age. The details of their management and the duodenal cannulas are given in Sedgman et al. (1985). Cannulas (Ash, 1962; Mould B) were used in the ileum and placed approximately $150 \mathrm{~mm}$ cranial to the ileo-caecal junction.

The intact calves in Expt 2 were kept in $1.8 \times 1.2 \mathrm{~m}$ galvanized iron pens with expanded metal floors and were not restrained in any way.

\section{Experimental design}

All experiments (1 (a), 1(b) and 2) were of $4 \times 4$ Latin square design with 9-d periods.

\section{Diets}

The calves fitted with re-entrant cannulas were allocated their first experimental diet at about 1 week after surgery. The amount of diet offered daily to each calf was $50 \mathrm{~g}$ dry matter $(\mathrm{DM}) / \mathrm{unit}$ metabolic body size $\left(\mathrm{kg}\right.$ live weight $\mathrm{t}^{0-75}$ ).

The composition of the four protein-limiting diets that were used in all three experiments is given in Table 1, whilst the composition of the ingredients is given in Table 2. Protein-limiting diets were used to ensure that excessive protein was not present in the control diet. For a calf of $50 \mathrm{~kg}$ live weight given $50 \mathrm{~g} \mathrm{DM} / \mathrm{kg}$ live weight ${ }^{0 \cdot 75}$, a minimum dietary concentration of $254 \mathrm{~g}$ protein $/ \mathrm{kg} \mathrm{DM}$ would be required to achieve $0.75 \mathrm{~kg}$ live-weight gain/d, which would be possible with this energy intake (Agricultural Research Council, 1980). The control diet contained $228 \mathrm{~g}$ protein $/ \mathrm{kg}$ DM. The four diets, P0, P30, $\mathrm{P} 50$ and $\mathrm{P} 70$, contained $0,300,500$ and $700 \mathrm{~g} / \mathrm{kg}$ protein respectively derived from Pruteen.

\section{Expt $1(a$ and $b)$. Collection and sampling of digesta}

Each diet was given at $12 \mathrm{~h}$ intervals, usually at 08.30 and 20.30 hours, for $9 \mathrm{~d}$. Collections of digesta for $12 \mathrm{~h}$ after the morning feed were made at the ileum on the $3 \mathrm{rd}$ and 7 th days and at the duodenum on the 5 th and 9 th days of each period of the Latin square.

The collection and sampling procedures at the duodenum were as reported in Sedgman et al. (1985), except that the samples were bulked for $0-2 \mathrm{~h}, 2-4 \mathrm{~h}, 4-6 \mathrm{~h}, 6-8 \mathrm{~h}, 8-10 \mathrm{~h}$ and 10-12 h after the experimental meal was given. The ileal outflow was collected into a $150 \mathrm{ml}$ polyethylene bottle attached to the calf by a small harness. The bottle was emptied when approximately half-full and also at hourly intervals after feeding. The ileal digesta were treated in a similar manner to the duodenal digesta, except that the proportion of digesta taken as a sample varied from 0.02 to 0.50 between time-periods, but was constant within a given time-period. This arose from the large variation in the outflow of digesta at the ileum. The ileal samples were bulked for 2 -h periods for subsequent analysis. 
Digestibility of single-cell protein in the calf

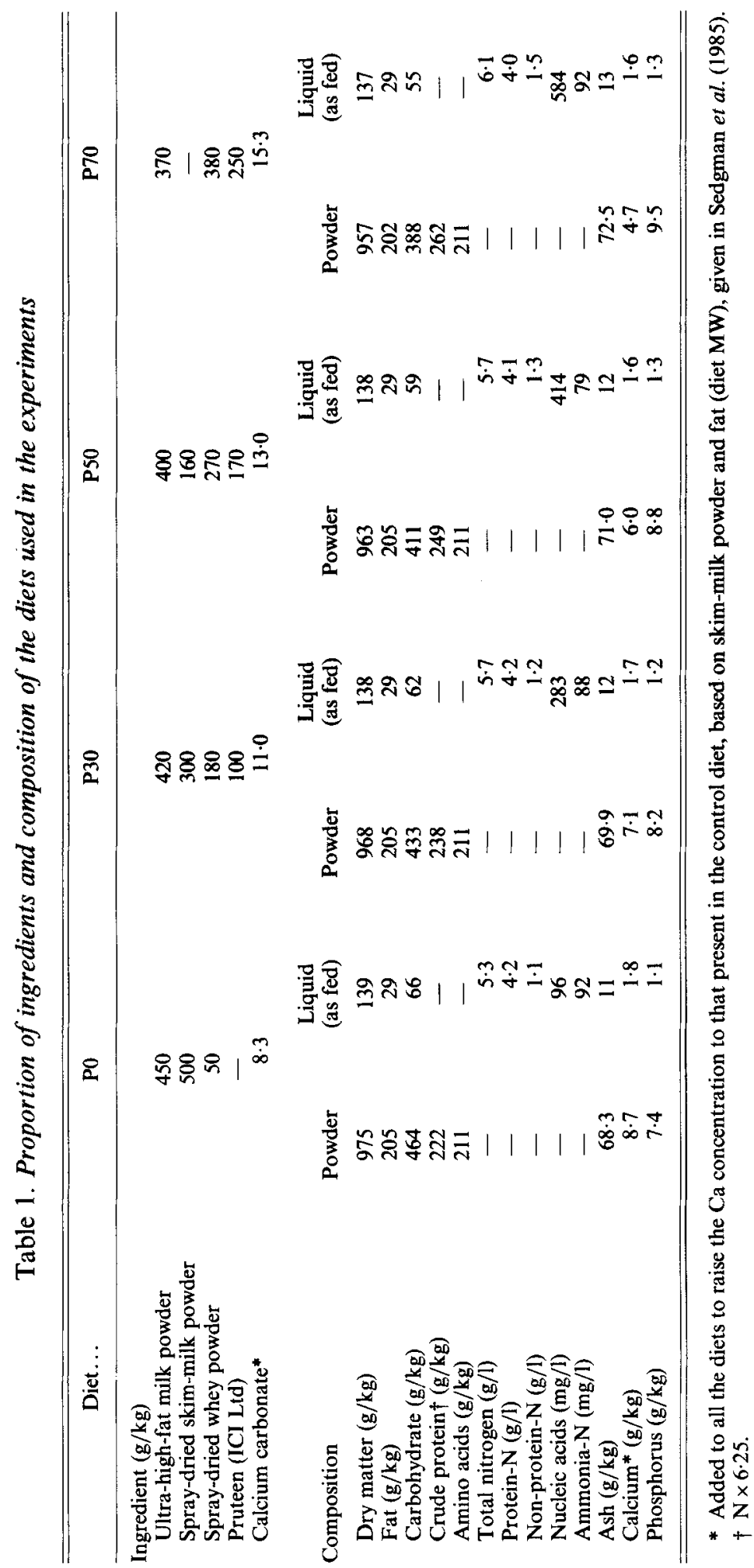


Table 2. Composition of the ingredients of the diets $(\mathrm{g} / \mathrm{kg}$ powder)

\begin{tabular}{|c|c|c|c|c|c|}
\hline & $\begin{array}{c}\text { Diet } \\
\text { L* }^{*}\end{array}$ & $\begin{array}{l}\text { Ultra-high- } \\
\text { fat milk } \\
\text { powder }\end{array}$ & $\begin{array}{l}\text { Spray-dried } \\
\text { skim-milk } \\
\text { powder }\end{array}$ & $\begin{array}{l}\text { Spray-dried } \\
\text { whey powder }\end{array}$ & $\begin{array}{c}\text { Pruteen } \\
\text { (ICI Ltd) } \\
\text { bacterial } \\
\text { protein }\end{array}$ \\
\hline Dry matter & 969 & 984 & 968 & 957 & 916 \\
\hline Fat $\ddagger$ & 220 & 451 & $3 \cdot 2$ & $9 \cdot 2$ & 126 \\
\hline $\begin{array}{l}\text { Lactose and other } \\
\text { carbohydrates }\end{array}$ & 418 & 381 & 519 & 647 & $58 \S$ \\
\hline Ash & $66 \cdot 8$ & 52.9 & $79 \cdot 9$ & 89.4 & $76 \cdot 0$ \\
\hline Crude protein $\|$ & 269 & 82 & 357 & 122 & 740 \\
\hline Amino acids & 285 & 60 & 357 & 101 & 600 \\
\hline Calcium & 10.8 & 4.9 & $12 \cdot 2$ & $7 \cdot 3$ & 0.6 \\
\hline Phosphorus & $8 \cdot 6$ & $4 \cdot 6$ & $9 \cdot 9$ & $7 \cdot 0$ & $20 \cdot 6$ \\
\hline
\end{tabular}

* $800 \mathrm{~g}$ spray-dried skim-milk powder $/ \mathrm{kg}, 200 \mathrm{~g}$ fat $/ \mathrm{kg}$. Vitamin and mineral mixture $(/ \mathrm{kg}$ dry matter $): 300 \mathrm{mg}$ magnesium as $\mathrm{MgCl}_{2} .6 \mathrm{H}_{2} \mathrm{O}, 100 \mathrm{mg}$ iron as $\mathrm{FeC}_{6} \mathrm{H}_{5} \mathrm{O}_{7} .5 \mathrm{H}_{2} \mathrm{O}, 40 \mathrm{mg}$ manganese as $\mathrm{MnSO}_{4} .4 \mathrm{H}_{2} \mathrm{O}, 20 \mathrm{mg}$ zinc as $\mathrm{ZnSO}_{4} .7 \mathrm{H}_{2} \mathrm{O}, 10 \mathrm{mg}$ copper as $\mathrm{CuSO}_{4}, 5 \mathrm{H}_{2} \mathrm{O}, 100 \mu \mathrm{g}$ cobalt as $\mathrm{CoSO}_{4} .5 \mathrm{H}_{2} \mathrm{O}, 120 \mu \mathrm{g}$ iodine as $\mathrm{KI}, 9.01 \mathrm{mg}$ retinol and $1.05 \mu \mathrm{g}$ cholecalciferol as Rovimix Type A500 (31.5 mg) and Rovimix A+D (4:1) Type 500 (27.5 mg), $20 \mathrm{mg} \alpha$-tocopherol as Rovimix E25 $(80 \mathrm{mg}), 30 \mu \mathrm{g}$ cyanocobalamin, $50 \mathrm{mg}$ butylated hydroxytoluene.

$+550 \mathrm{~g}$ spray-dried whey powder $/ \mathrm{kg}, 450 \mathrm{~g}$ fat $/ \mathrm{kg}$. Vitamin and mineral mixture, $2 \cdot 5$ times those in diet $\mathrm{L}$.

$\ddagger$ Fat in ultra-high-fat milk powder and spray-dried high-fat milk powder consisted of tallow:palm oil:soya lecithin in proportions of $13: 6: 1$ (by weight). Fat was incorporated by mechanical homogenization into liquid before spray-drying.

$\S$ By difference.

$\| \mathrm{N} \times 6.38$ for milk and milk by-products; $\mathrm{N} \times 6.25$ for non-milk products.

\section{Relation between Expt $1(a)$ and Expt 2}

Each intact calf in Expt 2 was paired with a cannulated calf in Expt 1(a), on the basis of similar birth weight. Each intact calf was given the same diet, in the same sequence and for the same length of time, i.e. $9 \mathrm{~d}$, as its cannulated counterpart. For the first $3 \mathrm{~d}$ of each period, the intake of diet was varied so that the weight of a pair of calves was the same. For the last $6 \mathrm{~d}$ of each period, the intake of diet was the same as that of the cannulated calf. During this $6 \mathrm{~d}$ period, urine and faeces were collected and sampled from the intact calf by the method described by Stobo et al. (1979), to enable calculation of apparent digestibilities, absorptions and retentions.

\section{Expt $I(b)$. Use of radioisotopes as protein markers}

To determine the true digestibility of protein, it is necessary to differentiate between the protein derived from the diet and that of endogenous origin. For this purpose, ${ }^{3} \mathrm{H}$ was used as a marker for milk protein and ${ }^{35} \mathrm{~S}$ as a marker for Pruteen in Expt 1(b).

It was not feasible to give diets to the calves in which all the protein was labelled; hence small quantities of ${ }^{3} \mathrm{H}$-labelled goats' milk and ${ }^{35} \mathrm{~S}$-labelled Pruteen were added to the liquid diets as markers. Goats' milk rather than cows' milk had to be used because of the impracticability of giving a cow an extremely large dose of radioactivity.

Production of ${ }^{3} \mathrm{H}$-labelled milk. A goat was injected with $20 \mathrm{mCi} \mathrm{L-}\left[{ }^{3} \mathrm{H}\right]$ lysine (Amersham International plc, Amersham, Bucks) into the jugular vein after it had been 'milked-out' using 2 i.u. oxytocin. After 1 h, 2 i.u. oxytocin were injected and the goat milked. This was repeated four times at $3-\mathrm{h}$ intervals. On the $2 \mathrm{nd}$ day, the goat was milked five times at $3-\mathrm{h}$ intervals, after injecting 2 i.u. before each milking. The goat was then milked twice daily for a further $5 \mathrm{~d}$ without the use of oxytocin. The milk obtained was frozen at $-20^{\circ}$ until needed. Of the ${ }^{3} \mathrm{H}$ dose, $\mathbf{0} \cdot 3$ was recovered in the milk during the $7 \mathrm{~d}$ period. 
Production of ${ }^{35}$ S-labelled bacteria (Methylomonas methylotropha). $\mathrm{Mg}^{35} \mathrm{SO}_{4}$ was used by ICI Ltd as the source of the $\mathrm{S}$ in the nutrient broth used to grow the bacteria. The commercial plant could not be used to produce the ${ }^{35}$ S-labelled Pruteen because of contamination and a scaled-down laboratory fermentor $\left(\mathrm{m}^{3}\right.$ in volume) was used. The comparability of the ' $1 \mathrm{~m}^{3}$ ' and commercial Pruteen was tested for both the P30 and P70 diets in a calf fitted with duodenal and ileal re-entrant cannulas and it was concluded that the apparent digestibility of protein- $\mathrm{N}$ from mouth to terminal ileum was sufficiently similar for ' $1 \mathrm{~m}^{3}$ ' Pruteen to be used as a marker for the commercial Pruteen. The values for diet P30 were 0.71 and 0.78 and for diet P70 0.89 and 0.89 for the commercial and ' $1 \mathrm{~m}^{3}$, products respectively.

Labelling of diets and experimental routine. The original intention was to use ${ }^{3} \mathrm{H}$ and ${ }^{35} \mathrm{~S}$ together as markers. Unfortunately, the quenching that occurred due to the colour and nature of the digesta moved the ${ }^{3} \mathrm{H}$ and ${ }^{35} \mathrm{~S}$ spectra so close together that they were indistinguishable and it was not possible to tell quantitatively whether the disintegrations counted were derived from ${ }^{3} \mathrm{H}$ or ${ }^{35} \mathrm{~S}$. For this reason each $9 \mathrm{~d}$ period was effectively divided into two. In the first half, the ileal and duodenal collections were used to measure ${ }^{3} \mathrm{H}$ flow and in the second half to measure ${ }^{35} \mathrm{~S}$ flow.

Each ileal collection preceded a duodenal collection. There were two unlabelled feeds followed by two labelled feeds (penultimate and experimental feeds) before the ileal collection, whereas there were three unlabelled feeds followed by one labelled feed (experimental feed) before the duodenal collection. Each ${ }^{3} \mathrm{H}$ dose was approximately $7 \times 10^{7}$ disintegrations/min and each ${ }^{35} \mathrm{~S}$ dose $2-7 \times 10^{7}$ disintegrations $/ \mathrm{min}$ depending on the diet.

To determine the background count in duodenal and ileal digesta respectively, a duodenal sample was taken before the experimental feed and an ileal sample before the penultimate feed.

\section{Analytical methods}

Faeces and urine samples in Expt 2 were analysed as described by Ternouth et al. (1974). Digesta samples were analysed for total N (TN), non-protein-N (NPN), protein-N (PN) and $\mathrm{pH}$, by the methods described in Sedgman et al. (1985).

Owing to the length of time required for nucleic acid-N analysis, the determinations of DNA and RNA were made on one bulked sample from the five samples collected within a $12 \mathrm{~h}$ collection period and also on the pre-feeding samples by the method of McAllan \& Smith (1969). Similarly, one bulked sample for each $12 \mathrm{~h}$ collection period was analysed for amino acids (LKB 4102 analyser). Most amino acids were determined after hydrolysis of the sample with $6 \mathrm{M}$-hydrochloric acid at $110^{\circ}$ for $24 \mathrm{~h}$ by the method of Spackman et al. (1958), but cystine and methionine were determined by the method of Moore (1963). Ammonia-N was estimated using an automated method based on Technicon Instrument Co. Ltd (1969).

\section{Radioactivity measurements}

A sample (1 ml) was mixed with $2 \mathrm{ml}$ propan-2-ol (BDH Chemicals Ltd, Poole, Dorset) followed by $2 \mathrm{ml}$ tissue solubilizer (NCS; Amersham/Searle Corp). The mixture was left in the dark for $10 \mathrm{~min}$ or until the samples were digested; $0.5 \mathrm{ml}$ hydrogen peroxide was added and mixed for $5 \mathrm{~min}$. The lids of the scintillation vials were loosened and the samples warmed for 5-10 min at $40-50^{\circ}$ to allow decoloration to occur; $10 \mathrm{ml} 1 \mathrm{M}-\mathrm{HCl}$ : scintillation fluid (Instagel; Packard Instruments Co. Inc.) mixture (1:9, v/v) were added. Samples for ${ }^{3} \mathrm{H}$ counting were kept in the dark for 1 week to avoid chemiluminescence. Samples for ${ }^{35} \mathrm{~S}$ were also kept in the dark but were counted immediately. Counting was done in a Packard Tricarb 2450 scintillation counter. Counting efficiency was determined by the addition of $100 \mu \mathrm{l}$ standard solution containing a known amount of either ${ }^{3} \mathrm{H}$ or ${ }^{35} \mathrm{~S}$. 
Table 3. Expts 1 and 2. Mean liquid intake $(\mathrm{kg} / 12 \mathrm{~h})$ at the penultimate and experimental meals in Expt $1(a)$ and $1(b)$ and during the digestibility periods in Expt 2

\begin{tabular}{|c|c|c|c|c|c|}
\hline & \multirow[b]{2}{*}{ Meal } & \multicolumn{4}{|c|}{ Diet* } \\
\hline & & $\mathrm{P} 0$ & P30 & P50 & P70 \\
\hline $\begin{array}{l}\text { Expt } 1 \text { (a) } \\
\text { Duodenal collection }\end{array}$ & $\begin{array}{l}\text { Penultimate } \\
\text { Experimental }\end{array}$ & $\begin{array}{l}3 \cdot 4 \\
3 \cdot 4\end{array}$ & $\begin{array}{l}3 \cdot 3 \\
3 \cdot 4\end{array}$ & $\begin{array}{l}3 \cdot 4 \\
3 \cdot 3\end{array}$ & $\begin{array}{l}2 \cdot 9 \\
3 \cdot 2\end{array}$ \\
\hline Ileal collection & $\begin{array}{l}\text { Penultimate } \\
\text { Experimental }\end{array}$ & $\begin{array}{l}3.4 \\
3.4\end{array}$ & $\begin{array}{l}3.4 \\
3.4\end{array}$ & $\begin{array}{l}3 \cdot 4 \\
3 \cdot 2\end{array}$ & $\begin{array}{l}2 \cdot 9 \\
3 \cdot 1\end{array}$ \\
\hline $\begin{array}{l}\text { Expt } 1 \text { (b) } \\
\text { Duodenal collection }\end{array}$ & $\begin{array}{l}\text { Penultimate } \\
\text { Experimental }\end{array}$ & $\begin{array}{l}3 \cdot 4 \\
3 \cdot 3\end{array}$ & $\begin{array}{l}3 \cdot 4 \\
3 \cdot 3\end{array}$ & $\begin{array}{l}3 \cdot 4 \\
2 \cdot 9\end{array}$ & $\begin{array}{l}3 \cdot 0 \\
3 \cdot 2\end{array}$ \\
\hline Ileal collection & $\begin{array}{l}\text { Penultimate } \\
\text { Experimental }\end{array}$ & $\begin{array}{l}3 \cdot 4 \\
3 \cdot 1\end{array}$ & $\begin{array}{l}2 \cdot 9 \\
3 \cdot 4\end{array}$ & $\begin{array}{l}2 \cdot 5 \\
3 \cdot 1\end{array}$ & $\begin{array}{l}3 \cdot 1 \\
2 \cdot 9\end{array}$ \\
\hline Expt 2 & $\begin{array}{l}\text { Digestibility and } \\
\text { balance trial }\end{array}$ & $3 \cdot 3$ & $3 \cdot 2$ & $3 \cdot 0$ & $2 \cdot 6$ \\
\hline
\end{tabular}

* For details, see Tables 1 and 2.

\section{Statistical methods}

The results were analysed as $4 \times 4$ Latin squares with split-plots in time. The main effects of diets and time after feeding have been partitioned into linear and quadratic components where appropriate, using orthogonal polynomials. Since the use of orthogonal polynomials with unequal increments of Pruteen would give only approximate quadratic components, these have been omitted from the tables.

Although one calf was common to Expt l(a) and 1(b), the analysis was done on the assumption that eight different calves were used for the two experiments, and the results have been combined accordingly for the analyses.

Statistical comparison of the results that were common to Expt 1 (a) and 1 (b) showed that there were no significant differences between them. The analyses of variance were therefore made on the combined results. Apparent digestibility in the small intestine and from mouth to terminal ileum and apparent disappearance in the small intestine of all the variables measured were analysed.

In Expt 1(a) and 1(b), calves sometimes refused part or all of the feed offered. This, combined with inherent imbalances in the diets such as nucleic acids, resulted in variation in dietary intake. Ternouth et al. (1975) showed that the volume of the penultimate meal could have a significant effect on duodenal outflow, and so the intake at both the penultimate and experimental meals was used for multiple covariance analyses.

\section{RESULTS}

The liquid intakes of the calves given the four diets during the three experiments are given in Table 3.

Expt $1(a)$ and $1(b)$. Volume of digesta outflow and its composition at the duodenum and ileum

Volume, $\mathrm{pH}, \mathrm{TN}, \mathrm{PN}, \mathrm{NPN}$ and $\mathrm{NH}_{3}-\mathrm{N}$ outflows

The effect of time after feeding. The combined results for both Expt 1(a) and 1(b) are 


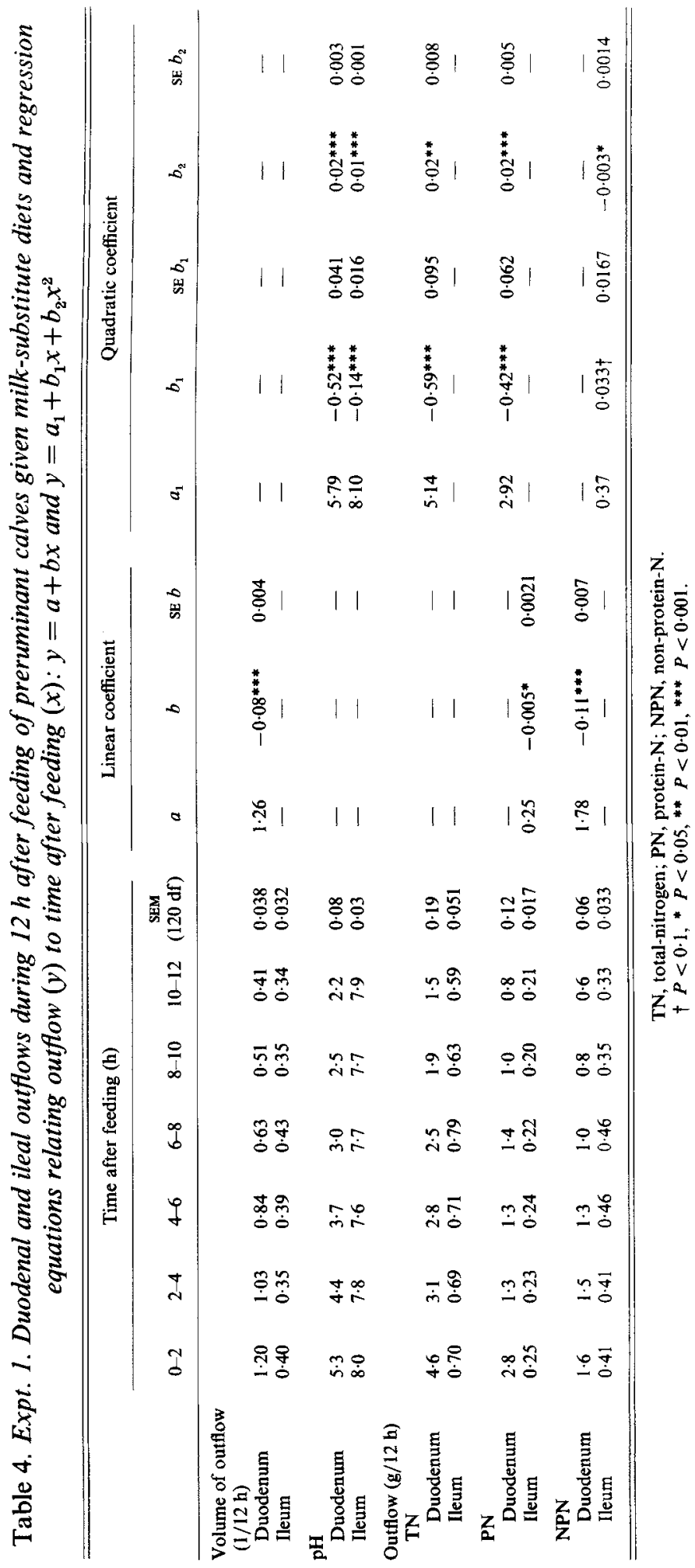


Table 5. Expt 1. Duodenal and ileal outflows during $12 \mathrm{~h}$ after feeding, and apparent digestibility of nitrogen fractions in preruminant calves given milk-substitute diets containing $O(P 0), 300 \mathrm{~g}(P 30), 500 \mathrm{~g}$ (P50) and $700 \mathrm{~g}$ (P70) bacterial protein (Pruteen; ICI Ltd)/kg total protein in the diets, and regression equations relating outflow $(y)$ to the proportion of Pruteen in the diet $(x): y=a+b x$

\begin{tabular}{|c|c|c|c|c|c|c|c|c|}
\hline & \multicolumn{5}{|c|}{ Diet $\uparrow$} & \multicolumn{3}{|c|}{ Linear coefficient $\ddagger$} \\
\hline & P0 & P30 & P50 & P70 & $\begin{array}{c}\text { SEM } \\
(12 \mathrm{df})\end{array}$ & $a$ & $b$ & $\mathrm{SE} b$ \\
\hline \multicolumn{9}{|l|}{$\begin{array}{l}\text { Volume of outflow } \\
(1 / 12 \mathrm{~h})\end{array}$} \\
\hline Duodenum & $4 \cdot 77$ & $4 \cdot 73$ & $4 \cdot 32$ & $4 \cdot 69$ & 0.18 & - & - & $\ldots$. \\
\hline Adjusted duodenum $\S$ & 4.60 & $4 \cdot 55$ & $4 \cdot 50$ & $4 \cdot 84$ & $0 \cdot 10$ & - & - & - \\
\hline Ileum & $2 \cdot 32$ & $1 \cdot 90$ & $2 \cdot 12$ & $2 \cdot 64$ & $0 \cdot 30$ & 一 & - & - \\
\hline \multicolumn{9}{|l|}{$\mathrm{pH}$} \\
\hline \multicolumn{9}{|l|}{ Duodenum } \\
\hline $0-2 \mathrm{~h}$ & $5 \cdot 2$ & $5 \cdot 3$ & $5 \cdot 3$ & $5 \cdot 3)$ & \multirow{6}{*}{$0 \cdot 16$} & \multirow{6}{*}{-} & \multirow{6}{*}{ - } & \multirow{6}{*}{-} \\
\hline $2-4 h$ & $4 \cdot 1$ & $4 \cdot 4$ & $4 \cdot 4$ & $4 \cdot 6$ & & & & \\
\hline $4-6 h$ & $3 \cdot 3$ & $3 \cdot 8$ & $3 \cdot 9$ & 3.7 & & & & \\
\hline $6-8 \mathrm{~h}$ & $3 \cdot 0$ & $3 \cdot 1$ & $3 \cdot 1$ & $2 \cdot 8$ & & & & \\
\hline $8-10 h$ & $2 \cdot 7$ & $2 \cdot 5$ & $2 \cdot 5$ & $2 \cdot 2$ & & & & \\
\hline $10-12 \mathrm{~h}$ & $2 \cdot 5$ & $2 \cdot 2$ & $2 \cdot 1$ & $2 \cdot 0)$ & & & & \\
\hline \multicolumn{9}{|l|}{ lleum } \\
\hline $0-2 \mathrm{~h}$ & $8 \cdot 0$ & $7 \cdot 9$ & $8 \cdot 0$ & $7 \cdot 9)$ & \multirow{6}{*}{0.006} & \multirow{6}{*}{$7 \cdot 9$} & \multirow{6}{*}{$-0 \cdot 3^{*}$} & \multirow{6}{*}{$0 \cdot 15$} \\
\hline $2-4 h$ & $8 \cdot 0$ & $7 \cdot 7$ & $7 \cdot 8$ & $7 \cdot 8$ & & & & \\
\hline $4-6 h$ & $7 \cdot 9$ & $7 \cdot 3$ & $7 \cdot 6$ & $7 \cdot 4$ & & & & \\
\hline $6-8 \mathrm{~h}$ & $7 \cdot 9$ & $7 \cdot 6$ & $7 \cdot 7$ & $7 \cdot 5$ & & & & \\
\hline $8-10 \mathrm{~h}$ & $7 \cdot 9$ & $7 \cdot 7$ & $7 \cdot 8$ & $7 \cdot 6$ & & & & \\
\hline $10-12 h$ & $8 \cdot 0$ & $7 \cdot 8$ & $7 \cdot 9$ & $7 \cdot 8)$ & & & & \\
\hline \multicolumn{9}{|l|}{ Intake $(\mathrm{g} / 12 \mathrm{~h})$} \\
\hline TN & $17 \cdot 0$ & $18 \cdot 4$ & $17 \cdot 4$ & $19 \cdot 4$ & - & - & - & - \\
\hline PN & $12 \cdot 9$ & $13 \cdot 3$ & $11 \cdot 3$ & $12 \cdot 4$ & - & - & - & - \\
\hline NPN & $3 \cdot 1$ & $3 \cdot 5$ & $3 \cdot 6$ & $4 \cdot 3$ & - & - & - & - \\
\hline \multicolumn{9}{|l|}{ Outflow $(\mathrm{g} / 12 \mathrm{~h})$} \\
\hline \multicolumn{9}{|l|}{ TN } \\
\hline Duodenum & $15 \cdot 4$ & 16.9 & $16 \cdot 0$ & $18 \cdot 2$ & $1 \cdot 03$ & - & - & - \\
\hline Adjusted duodenum $\S$ & $16 \cdot 9$ & $16 \cdot 3$ & 16.9 & $16 \cdot 3$ & 0.76 & - & - & - \\
\hline Ileum & $2 \cdot 9$ & $4 \cdot 5$ & $4 \cdot 0$ & $5 \cdot 2$ & $0 \cdot 40$ & $3 \cdot 1$ & $2 \cdot 8 * *$ & 0.78 \\
\hline \multicolumn{9}{|l|}{ PN } \\
\hline Duodenum & $7 \cdot 4$ & $8 \cdot 6$ & $8 \cdot 4$ & $9 \cdot 8$ & 0.69 & $7 \cdot 4$ & $3 \cdot 1^{*}$ & $1 \cdot 33$ \\
\hline Adjusted duodenum§ & $6 \cdot 9$ & $7 \cdot 6$ & $9 \cdot 7$ & $10 \cdot 1$ & $0 \cdot 40$ & $6 \cdot 7$ & $5 \cdot 0 * * *$ & 0.76 \\
\hline Ileum & $0 \cdot 6$ & 1.4 & $1 \cdot 4$ & $2 \cdot 0$ & $0 \cdot 18$ & $0 \cdot 7$ & $1 \cdot 8 * * *$ & $0 \cdot 34$ \\
\hline \multicolumn{9}{|l|}{ NPN } \\
\hline Duodenum & $7 \cdot 2$ & $7 \cdot 0$ & $6 \cdot 3$ & $6 \cdot 5$ & 0.40 & - & - & - \\
\hline Adjusted duodenum§ & 7.9 & $7 \cdot 3$ & $6 \cdot 6$ & $5 \cdot 3$ & 0.42 & $8 \cdot 1$ & $-3 \cdot 7 * *$ & 1.01 \\
\hline Ileum & $2 \cdot 0$ & $2 \cdot 3$ & $2 \cdot 5$ & $2 \cdot 9$ & $0 \cdot 24$ & 1.9 & $1 \cdot 3^{*}$ & 0.46 \\
\hline \multicolumn{9}{|l|}{ Ammonia-N } \\
\hline Duodenum & 0.37 & $0 \cdot 41$ & $0 \cdot 31$ & $0 \cdot 36$ & - & - & - & - \\
\hline Ileum & 0.20 & $0 \cdot 27$ & $0 \cdot 15$ & $0 \cdot 23$ & - & - & - & - \\
\hline \multicolumn{9}{|l|}{$\begin{array}{l}\text { Apparently absorbed } \\
\text { in the small intestine } \\
(\mathrm{g} / 12 \mathrm{~h})\end{array}$} \\
\hline TN & $12 \cdot 5$ & 12.4 & $12 \cdot 0$ & $13 \cdot 1$ & 0.98 & - & - & - \\
\hline PN & 6.8 & $7 \cdot 2$ & $7 \cdot 0$ & $7 \cdot 9$ & $0 \cdot 77$ & - & - & - \\
\hline NPN & $5 \cdot 2$ & $4 \cdot 7$ & 3.9 & 3.6 & $0 \cdot 26$ & $5 \cdot 2$ & $-2 \cdot 5^{* * *}$ & 0.50 \\
\hline $\mathrm{NH}_{3}-\mathrm{N}$ & 0.18 & $0 \cdot 14$ & 0.15 & $0 \cdot 13$ & - & - & - & -- \\
\hline
\end{tabular}


Table 5. (cont.)

\begin{tabular}{|c|c|c|c|c|c|c|c|c|}
\hline & \multicolumn{5}{|c|}{$\operatorname{Diet}^{\dagger}$} & \multicolumn{3}{|c|}{ Linear coefficient $\ddagger$} \\
\hline & P0 & P30 & P50 & P70 & $\begin{array}{l}\text { SEM } \\
(12 \mathrm{df})\end{array}$ & $a$ & $b$ & SE $b$ \\
\hline \multicolumn{9}{|c|}{$\begin{array}{l}\text { Apparent digestibility } \\
\text { in the small intestine }\end{array}$} \\
\hline TN & 0.81 & $0 \cdot 73$ & $0 \cdot 75$ & $0 \cdot 72$ & $0 \cdot 032$ & - & - & - \\
\hline PN & 0.91 & 0.79 & 0.82 & 0.80 & 0.038 & - & - & - \\
\hline NPN & 0.72 & 0.67 & 0.61 & 0.55 & 0.022 & 0.72 & $-0 \cdot 24^{* * *}$ & 0.044 \\
\hline $\mathrm{NH}_{3}-\mathrm{N}$ & $0 \cdot 46$ & $0 \cdot 37$ & $0 \cdot 41$ & 0.37 & - & - & - & - \\
\hline \multicolumn{9}{|c|}{$\begin{array}{l}\text { Apparent digestibility } \\
\text { from mouth to ileum }\end{array}$} \\
\hline TN & 0.83 & 0.76 & 0.78 & 0.71 & 0.022 & 0.82 & $-0 \cdot 14^{* *}$ & 0.043 \\
\hline PN & 0.95 & 0.89 & 0.88 & 0.82 & 0.015 & 0.95 & $-0 \cdot 17^{* * *}$ & 0.030 \\
\hline NPN & $0 \cdot 27$ & $0 \cdot 36$ & 0.34 & 0.25 & 0.060 & - & - & - \\
\hline $\mathrm{NH}_{3}-\mathrm{N}$ & $0 \cdot 30$ & $0 \cdot 27$ & $0 \cdot 34$ & $0 \cdot 24$ & $\cdots$ & - & - & - \\
\hline
\end{tabular}

TN, total-N; PN, protein-N; NPN, non-protein-N.

${ }^{*} P<0.05,{ }^{* *} P<0.01,{ }^{* * *} P<0.001$.

$\dagger$ For details, see Tables 1 and 2.

$\ddagger$ Regression coefficients with their standard errors are actual values $\times 10^{3}$.

$\S$ Values adjusted for differences in intake between treatments, with standard error based on $10 \mathrm{df}$.

given in Table 4. At the duodenum, as expected, there was a significant decrease in volume of digesta outflow, its $\mathrm{pH}$ and outflows of TN, PN and NPN with time after feeding, although the concentrations of TN, PN and NPN varied little with time.

At the ileum there were no obvious differences in the volume of outflow with time after feeding, but the $\mathrm{pH}$ decreased to a minimum after $5 \mathrm{~h}$ for all diets and then increased. PN outflow decreased with time after feeding but NPN outflow increased to a maximum at about $6 \mathrm{~h}$ after feeding and then declined.

The effect of concentration of Pruteen (Table 5). Volume of outflow, both at the duodenum and ileum, was unaffected by Pruteen concentration. At the duodenum, only PN outflow showed a significant increase as the amount of Pruteen in the diet was increased. However, when the results were expressed as accumulated outflows, there was a tendency for an increase in outflow of TN and a decrease in outflow of NPN. The pH of the duodenal digesta of calves given diets containing Pruteen tended to be higher than that of calves given the milk diet up to $6 \mathrm{~h}$ after feeding but lower thereafter, so that the total decline was $0.6 \mathrm{pH}$ units greater than that for diet $\mathrm{P} 0$.

At the ileum, TN, PN and NPN outflows and $\mathrm{pH}$ were all significantly affected by the amount of Pruteen in the diet. Diets containing Pruteen always gave lower $\mathrm{pH}$ values throughout the $12 \mathrm{~h}$ collection period. At $5 \mathrm{~h}$ after feeding, when the minimum $\mathrm{pH}$ was observed, the difference between diets P0 and P70 was $0.45 \mathrm{pH}$ units. The ileal outflow of TN and concentration of TN were higher at all times after giving diets containing Pruteen and resulted in more than 1.5-fold increase in outflow during $12 \mathrm{~h}$ for diet P70 compared with that for diet P0. The proportional increases in outflow and concentration of PN were even more marked than for TN, with more than a three-fold increase in outflow for diet P70 compared with diet P0. The increase in NPN concentration and outflow was not due to increased proteolysis, since there was a proportional decrease of 0.10 in the ratio NPN:TN in ileal digesta of calves given diet P70 compared with that of calves given diet P0. 
Table 6. Expt 1. Mean amino acid intake at the experimental meal (g)

\begin{tabular}{|c|c|c|c|c|}
\hline $\operatorname{Diet}^{*} \ldots$ & Po & P30 & P50 & P70 \\
\hline Aspartic acid & $8 \cdot 34$ & $8 \cdot 58$ & $9 \cdot 72$ & $10 \cdot 84$ \\
\hline Threonine & 4.93 & 4.59 & $5 \cdot 02$ & $5 \cdot 51$ \\
\hline Serine & $5 \cdot 53$ & $4 \cdot 26$ & $4 \cdot 54$ & $4 \cdot 66$ \\
\hline Glutamic acid & $17 \cdot 66$ & $15 \cdot 41$ & 14.98 & $14 \cdot 40$ \\
\hline Proline & $8 \cdot 17$ & $6 \cdot 50$ & $5 \cdot 35$ & $4 \cdot 25$ \\
\hline Glycine & 1.98 & $2 \cdot 76$ & 3.69 & 4.44 \\
\hline Alanine & $3 \cdot 45$ & $4 \cdot 59$ & $6 \cdot 20$ & $7 \cdot 69$ \\
\hline Cystine & $1 \cdot 10$ & 0.97 & $1 \cdot 01$ & $1 \cdot 75$ \\
\hline Valine & $4 \cdot 66$ & $5 \cdot 33$ & $4 \cdot 40$ & $4 \cdot 38$ \\
\hline Methionine & $2 \cdot 38$ & $2 \cdot 31$ & $2 \cdot 25$ & $2 \cdot 08$ \\
\hline Isoleucine & 3.99 & $4 \cdot 52$ & 3.96 & $3 \cdot 75$ \\
\hline Leucine & $9 \cdot 51$ & $9 \cdot 15$ & $8 \cdot 61$ & $7 \cdot 56$ \\
\hline Tyrosine & 3.89 & 3.48 & $3 \cdot 23$ & $3 \cdot 12$ \\
\hline Phenylalanine & $4 \cdot 19$ & $4 \cdot 02$ & $3 \cdot 75$ & $3 \cdot 72$ \\
\hline Histidine & $2 \cdot 11$ & $2 \cdot 25$ & $1 \cdot 83$ & $1 \cdot 73$ \\
\hline Lysine & $7 \cdot 00$ & $6 \cdot 67$ & $6 \cdot 49$ & 6.65 \\
\hline Arginine & $2 \cdot 68$ & $3 \cdot 59$ & 3.69 & $4 \cdot 00$ \\
\hline Total & $91 \cdot 57$ & 88.98 & $88 \cdot 72$ & $90 \cdot 53$ \\
\hline
\end{tabular}

* For details, see Tables 1 and 2.

As shown in Table 3, liquid intakes tended to decrease due to lower palatabilities when greater amounts of Pruteen were included in the diets. Variation also occurred between intakes at the penultimate and experimental meals. Covariance analysis of the ileal outflow of liquid, TN, PN or NPN on the intakes at the penultimate and experimental meals showed that there was no significant effect. However, the intake at the experimental but not at the penultimate meal had a significant effect on the duodenal outflow of these variables. Adjustment of the mean TN duodenal outflows (Table 5) did not alter the overall significance of the dietary effect, but adjustment of the mean PN outflows emphasized the increase and adjustment of the mean NPN outflow emphasized the decrease in duodenal outflow with increasing amounts of Pruteen in the diet. Unadjusted values were used to calculate the apparent absorption and digestibilities given in Table 5.

The amount of PN apparently absorbed from the small intestine tended to be greater and the amount of NPN apparently absorbed was significantly less with greater amounts of Pruteen in the diet.

Apparent digestibility of TN, PN and NPN in the small intestine all tended to decrease with greater amounts of Pruteen in the diet, but the effect was only significant for NPN. In contrast, apparent digestibility from mouth to ileum significantly decreased for $\mathrm{TN}$ and PN, but not for NPN, as the rate of inclusion of Pruteen increased.

Unfortunately acid was not added to the ileal samples obtained from the first calf in the Latin square and therefore missing values for $\mathrm{NH}_{3}-\mathrm{N}$ were calculated by the method of Yates (1933). There was no-significant treatment effect on duodenal or ileal outflow of $\mathrm{NH}_{3}-\mathrm{N}$, nor was there any obvious trend in apparent absorption of $\mathrm{NH}_{3}-\mathrm{N}$ in the small intestine or between mouth and terminal ileum.

\section{Amino acid outflow}

The results from Expt 1 (a) are given in Tables 6,7 and 8. Total amino acid intake for each diet was similar but the relative proportion of the individual amino acids to the total varied between diets (Table 6). The individual amino acid concentrations in the duodenal digesta 


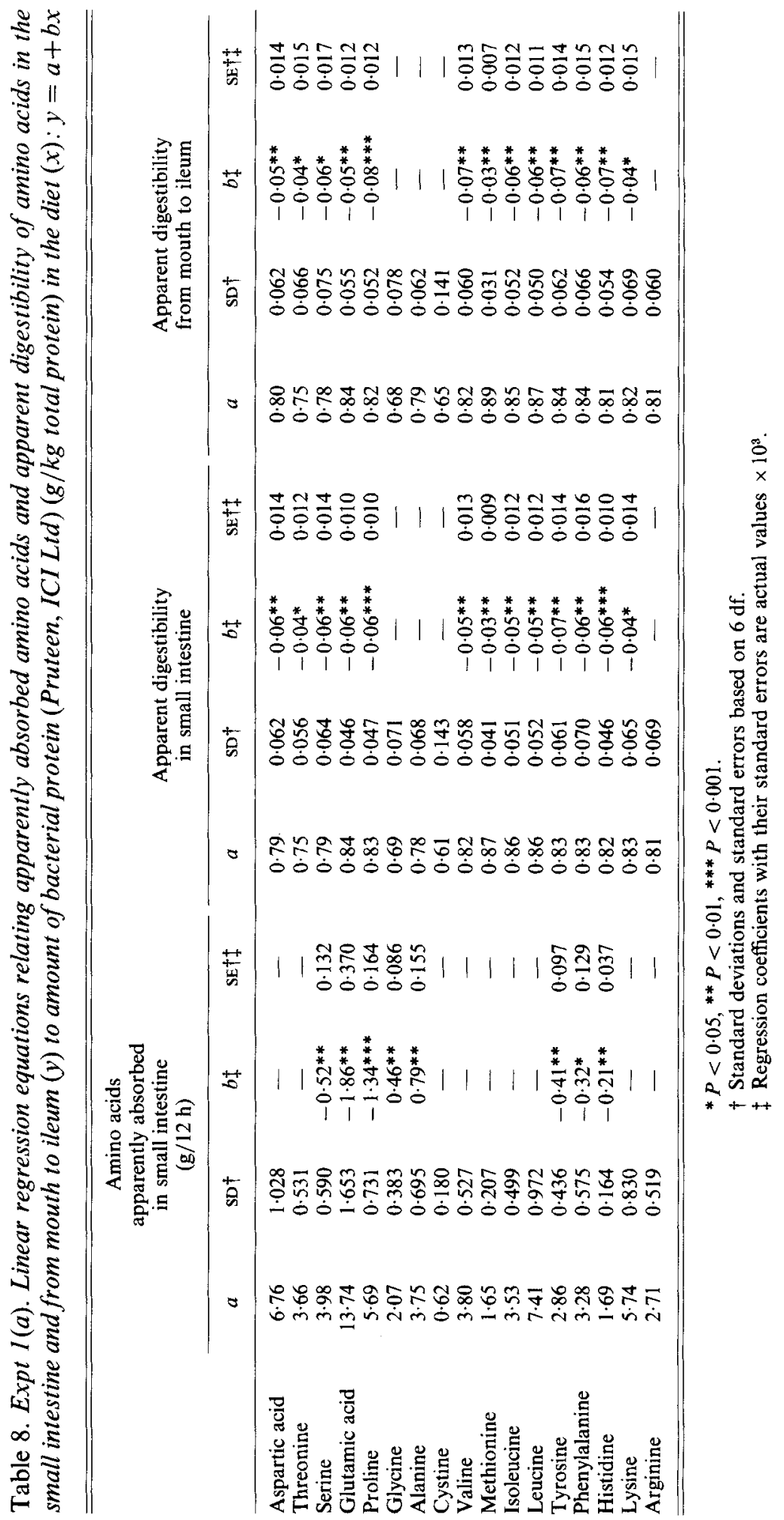


reflected those in the diet (Table 7). Adjustment by covariance of the individual amino acid concentrations in the duodenum for differences in concentrations in the diet resulted in no significant difference in concentration between treatments, with the exception of arginine. Thus little modification of the amino acid composition by secretion or absorption in the abomasum seems to occur.

The duodenal outflow of aspartic acid, threonine, glycine, alanine and arginine increased whereas the duodenal outflow of glutamic acid, proline, tyrosine and histidine decreased with increasing amount of Pruteen in the diet.

In contrast, at the ileum, the total amount of each amino acid increased significantly when more Pruteen was included in the diet (Table 7). When adjustments were made for the variation in intake of each amino acid, the treatment effects on valine, methionine, isoleucine, histidine and lysine remained significant. Thus, although changes in amino acid composition of the digesta occurred in the small intestine, there was still some dependence on the amino acid composition of the dietary protein.

In general, the greater the amount of an individual amino acid in the diet, the greater was the amount apparently absorbed in the small intestine. However, the apparent digestibility of practically all the amino acids in both the small intestine and between the mouth and terminal ileum decreased with increasing amounts of Pruteen in the diet (Table 8).

\section{Nucleic acid outflow}

The results, given in Table 9, were obtained only in Expt 1 (a) and several problems were encountered in their determination. Whereas there was close agreement between the measured amount of DNA in the liquid Pruteen-containing diets and that calculated from the DNA concentration in the constituent powder, for RNA the values in the liquid were considerably lower than expected from the concentration in the powder. This resulted in the DNA values measured in the samples of the liquid Pruteen-containing diets being higher than the RNA values for the same sample. Since the DNA and RNA concentrations in the Pruteen powder agreed with those determined by ICI Ltd, it is concluded that the RNA was degraded during reconstitution or storage of the diets, or both, possibly by an active ribonuclease from the Pruteen. However, incubation of RNA standard with Pruteen did not cause any loss of RNA. The considerably lower concentration of RNA, than of DNA, in the duodenal digesta from calves given the diets containing Pruteen is thought to reflect the lower RNA intake. The content of RNA in the ileal digesta was, as expected, higher than that of DNA. Assuming enzymic breakdown of RNA in the diet before feeding, dietary and duodenal concentrations of nucleic acids would be underestimated, but the ileal values would presumably indicate the true extent of the digestion of the nucleic acids. However, it is also possible that enzymic breakdown of RNA in the diet, together with digestion by endogenous enzymes, might give a higher overall digestion of RNA than would have occurred without this breakdown.

Thus, owing to the enzymic breakdown of RNA in the liquid diet, apparent digestibility of RNA-N and nucleic acid-N in the small intestine will be underestimated, whereas RNA intake calculated from the dry powder and observed outflow of RNA at the ileum should give a true estimate of digestibility up to the terminal ileum.

Whether expressed as concentrations or total amounts, outflow of RNA and DNA at the duodenum increased with greater dietary inclusion of Pruteen. When the duodenal outflow of nucleic acid- $\mathrm{N}$ was adjusted by covariance for differences in intake between treatments, it was no longer affected by diet.

In the ileal digesta, there was a slight tendency for RNA to increase with increasing amount of Pruteen in the diet but DNA remained fairly constant. 


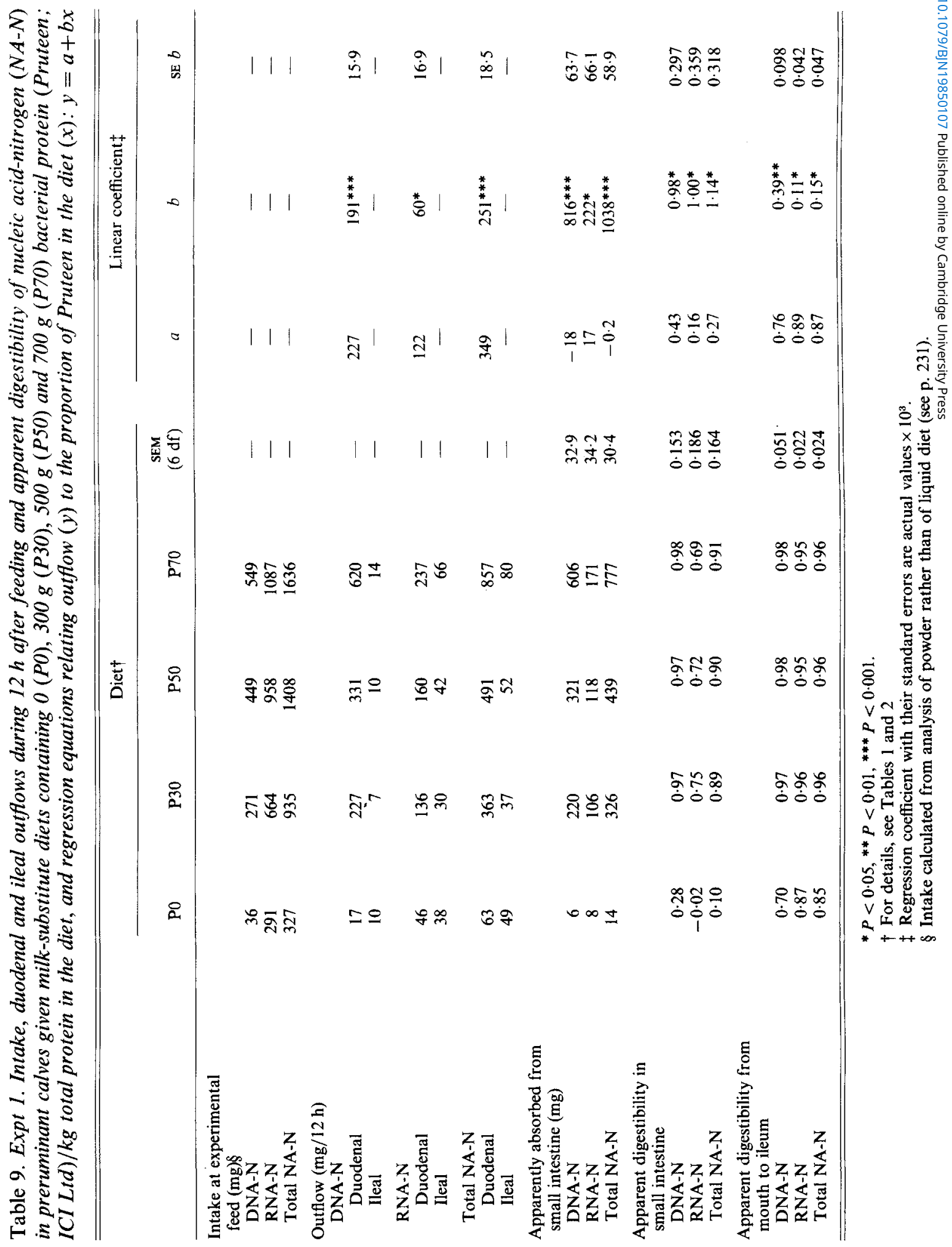


Table 10. Expt $1(b)$. Duodenal and ileal outflows of ${ }^{3} \mathrm{H}$ and ${ }^{35} \mathrm{~S}$ during $12 \mathrm{~h}$ after feeding preruminant calves milk-substitute diets containing bacterial protein (Pruteen, ICI Ltd), and regression equations relating outflow $(y)$ to time after feeding $(x): y=a+b x$

\begin{tabular}{|c|c|c|c|c|c|c|c|c|c|c|}
\hline \multirow[b]{2}{*}{$\begin{array}{c}\text { Outflow }\left(10^{-6}\right. \\
\text { disintegrations } / \mathrm{min})\end{array}$} & \multicolumn{7}{|c|}{ Time-interval after feeding (h) } & \multicolumn{3}{|c|}{ Linear coefficients } \\
\hline & $0-2$ & $2-4$ & $4-6$ & $6-8$ & $8-10$ & $10-12$ & $\begin{array}{c}\text { SEM } \\
(60 \mathrm{df})\end{array}$ & $a$ & $b$ & SE $b$ \\
\hline \multicolumn{11}{|l|}{${ }^{3} \mathrm{H}$} \\
\hline Duodenum & 13 & 12 & 11 & 10 & 6 & 5 & $1 \cdot 3$ & 19 & $-1 \cdot 6^{* * *}$ & 0.31 \\
\hline Ileum & 0.8 & 0.8 & 1.0 & 1.4 & 0.9 & $1 \cdot 1$ & $0 \cdot 15$ & - & -- & - \\
\hline \multicolumn{11}{|l|}{${ }^{35} \mathrm{~S}$} \\
\hline Duodenum & $0 \cdot 98$ & 0.74 & 0.66 & $0 \cdot 50$ & $0 \cdot 38$ & $0 \cdot 40$ & $0 \cdot 101$ & $1 \cdot 3$ & $-0 \cdot 1^{* * *}$ & $0 \cdot 02$ \\
\hline lleum & 0.36 & 0.19 & 0.23 & $0 \cdot 18$ & 0.20 & 0.23 & 0.051 & - & - & - \\
\hline
\end{tabular}

*** $P<0.01$

Since the amount of nucleic acids apparently absorbed from the small intestine significantly increased when more Pruteen was included in the diet, it appears that the calf has the capacity to absorb large quantities of nucleic acid from the small intestine and that the maximum capacity had not been reached at the levels used in this experiment. The apparent digestibilities of the nucleic acids in the small intestine and between mouth and terminal ileum were very similar for diets P30, P50 and P70 but much lower for diet P0. However, the amount of undigested nucleic acid in the ileal digesta for diet P0 was similar to that for the other three diets. This low level must have arisen from an endogenous contribution of nucleic acids from the bacterial flora and sloughed-off cells.

\section{${ }^{3} \mathrm{H}$ and ${ }^{35} \mathrm{~S}$ outflow}

The results obtained in Expt 1(b) are given in Tables 10 and 11. Although intakes of the isotopes at individual experimental meals preceding a duodenal collection varied considerably, the variation between the mean values for each diet was not as great, and neither the intake of ${ }^{3} \mathrm{H}$ nor of ${ }^{35} \mathrm{~S}$ had a significant effect on their duodenal outflows. Intakes at the penultimate and experimental feeds preceding an ileal collection were also variable but did have a significant effect on the outflow of the isotopes at the ileum. The adjusted outflow values are given in Table 11.

The effect of time after feeding. The duodenal outflow of ${ }^{3} \mathrm{H}$ decreased and the concentration of ${ }^{3} \mathrm{H}$ increased significantly with time after feeding for all diets, except $\mathrm{P} 70$ where there was a decrease in the concentration of ${ }^{3} \mathrm{H}$. Concentration of ${ }^{3} \mathrm{H}$ during the first $3 \mathrm{~h}$ after feeding tended to be higher at greater rates of inclusion of Pruteen in the diet.

At the ileum, outflow of ${ }^{3} \mathrm{H}$ was not affected by time after feeding, even when adjusted for differences in ${ }^{3} \mathrm{H}$ intake. Concentration of ${ }^{3} \mathrm{H}$ in ileal digesta varied little with time after giving diet $\mathrm{P} 0$, but tended to be greater for the diets containing Pruteen.

The outflow of ${ }^{35} \mathrm{~S}$ at the duodenum decreased significantly with time after feeding, with no significant difference between diets. At the ileum, apart from an initially high value $1 \mathrm{~h}$ after giving diet $\mathrm{P} 0$, the outflow of ${ }^{35} \mathrm{~S}$ in the digesta was unaffected by time after feeding.

The effect of concentration of Pruteen. Since the intakes preceding the duodenal collections were variable but not significantly different, the duodenal outflows were expressed as accumulated recoveries (Sedgman, 1980). Recovery of ${ }^{3} \mathrm{H}$ was similar for all four diets whereas the recovery of ${ }^{35} \mathrm{~S}$ after feeding diet $\mathrm{P} 0$ was considerably higher than after feeding the other three diets. 


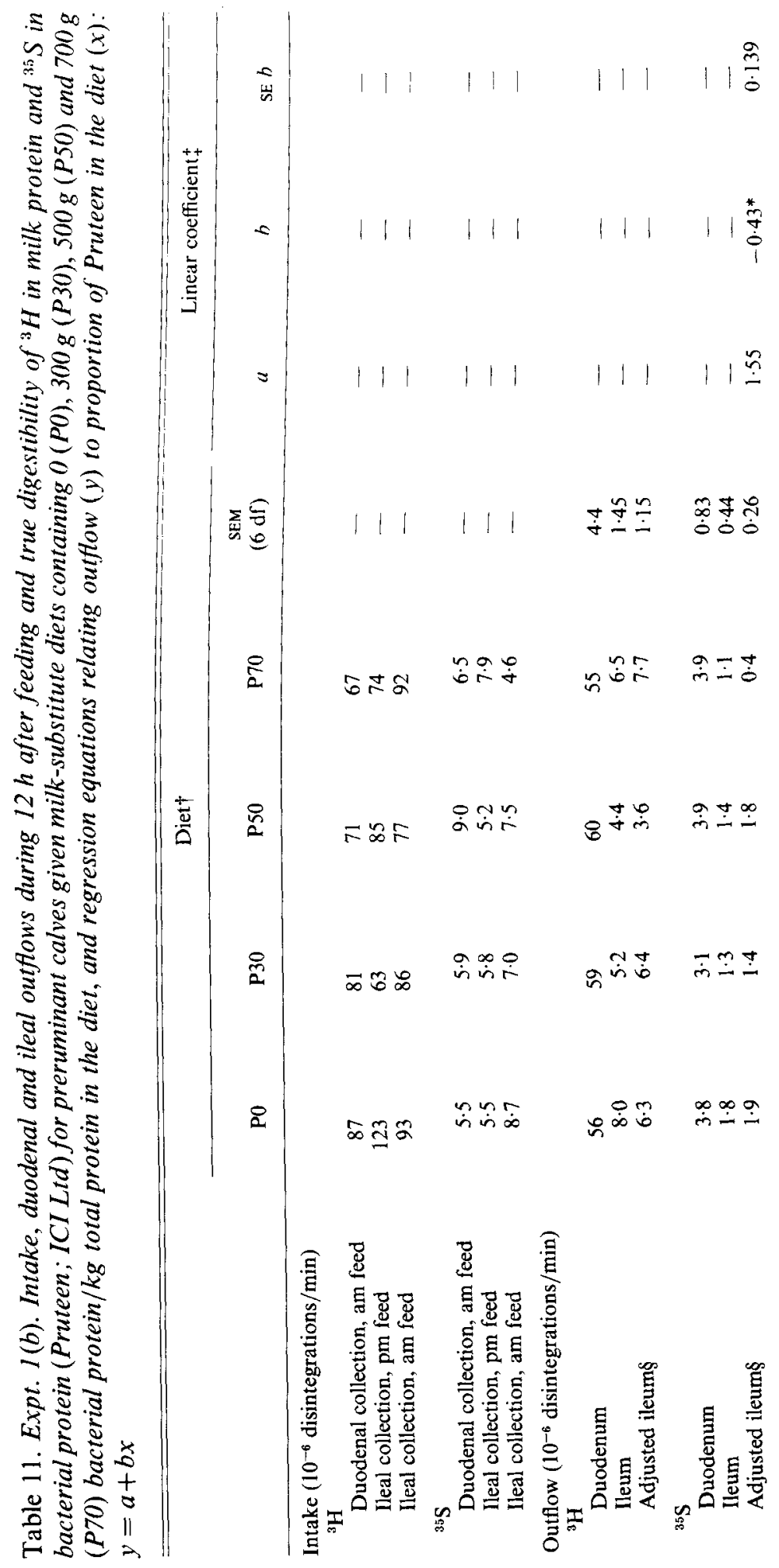




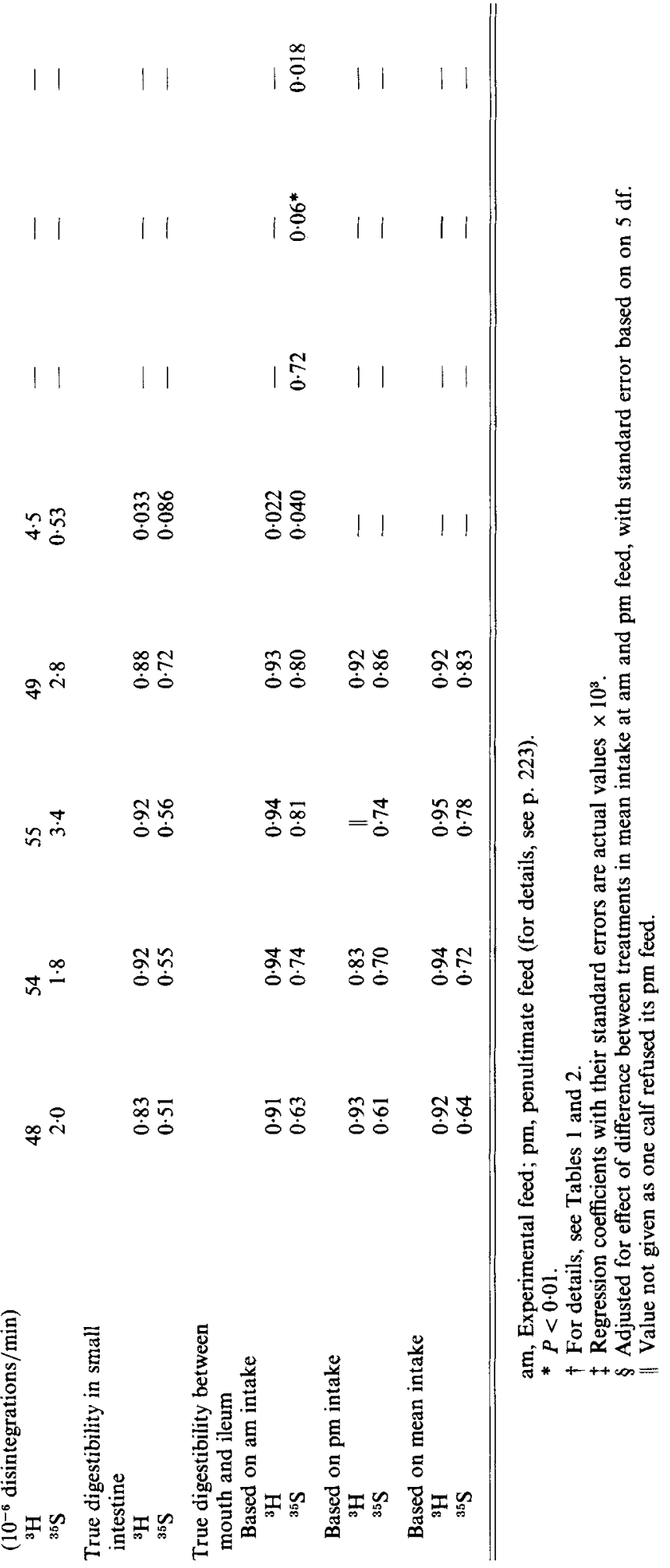


Table 12. Expt 2. Apparent digestibility of nutrients over the whole alimentary tract and retention of calcium and phosphorus in preruminant calves given diets containing $0(P 0), 300 \mathrm{~g}$ (P30), $500 \mathrm{~g}(P 50)$ and $700 \mathrm{~g}(P 70)$ bacterial protein (Pruteen; ICI Ltd) $/ \mathrm{kg}$ total protein in the diet, and regression equations relating digestibility $(y)$ to proportion of Pruteen in the diet $(x): y=a+b x$

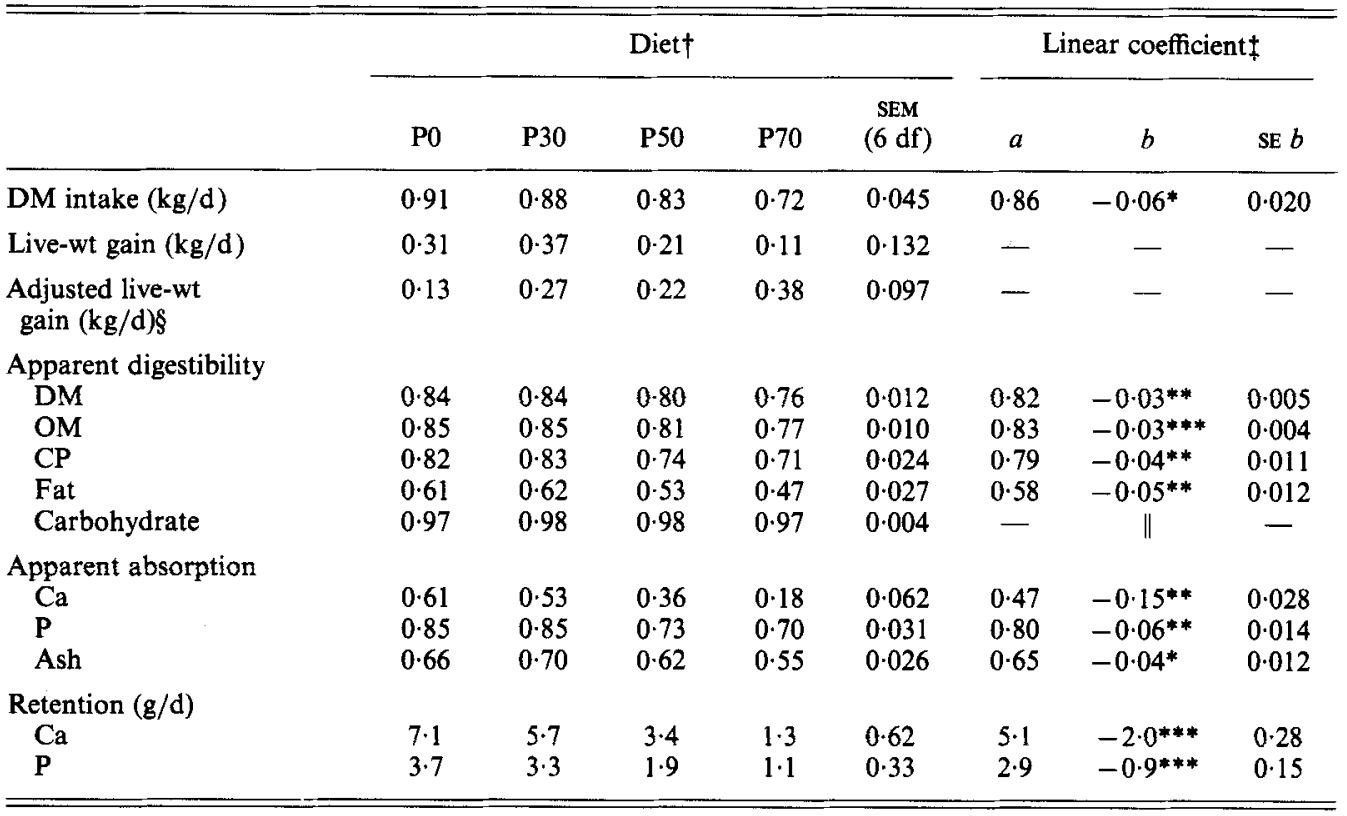

$\mathrm{DM}$, dry matter; OM, organic matter; $\mathrm{CP}$, crude protein $(\mathrm{N} \times 6.25)$.

${ }^{*} P<0.05,{ }^{* *} P<0.01,{ }^{* * *} P<0.001$.

+ For details, see Tables 1 and 2 .

$\ddagger$ Regression coefficients with their standard errors are actual values $\times 10^{3}$.

$\S$ Values adjusted for differences in DM intake between treatments, with standard error based on $5 \mathrm{df}$.

$\|$ A significant quadratic treatment effect but, because of unequal increments in proportion of Pruteen in the diet, the regression equation cannot be calculated since orthogonal polynomials were used in the analysis.

The ileal outflows of ${ }^{35} \mathrm{~S}$, adjusted for differences in intake between treatments, were similar to the unadjusted values, except that the adjusted outflow for diet P70 was much lower than the unadjusted value; there was a significant reduction in adjusted ileal outflow of ${ }^{35} \mathrm{~S}$ as more Pruteen was included.

The concentration of ${ }^{35} \mathrm{~S}$ in the ileal digesta stayed fairly constant after the diets containing Pruteen were given but, after diet P0 was given, there was an initial decrease in concentration from 1 to $3 \mathrm{~h}$ after feeding followed by a large increase to $12 \mathrm{~h}$.

The true digestibility in the small intestines of ${ }^{3} \mathrm{H}$ was similar for all diets but that of ${ }^{35} \mathrm{~S}$ tended to increase linearly as more Pruteen was included in the diet.

Since there were differences in intake at the penultimate and experimental meals before an ileal collection, true digestibilities between mouth and ileum were calculated using experimental, penultimate and the mean of the experimental and penultimate intakes. True digestibility of ${ }^{3} \mathrm{H}$ was unaffected by dietary treatment but the true digestibility of ${ }^{35} \mathrm{~S}$ between the mouth and ileum increased linearly with increasing inclusion of Pruteen. 
Table 13. Expt 2. Overall nitrogen metabolism of preruminant calves given diets containing 0 (P0), $300 \mathrm{~g}$ (P30), $500 \mathrm{~g}$ (P50) and $700 \mathrm{~g}$ (P70) bacterial protein (Pruteen; ICI Ltd)/kg total protein in the diet, and regression equations relating $N$ metabolism $(y)$ to proportion of Pruteen in the diet $(x): y=a+b x$

\begin{tabular}{|c|c|c|c|c|c|c|c|c|}
\hline & \multicolumn{5}{|c|}{$\operatorname{Diet}^{\dagger}$} & \multicolumn{3}{|c|}{ Linear coefficient $\ddagger$} \\
\hline & $\mathbf{P 0}$ & P30 & P50 & $\mathbf{P} 70$ & $\begin{array}{l}\text { SEM } \\
(6 \mathrm{df})\end{array}$ & $a$ & $b$ & SE $b$ \\
\hline $\mathrm{N}$ intake $(\mathrm{g} / \mathrm{d})$ & $32 \cdot 4$ & 33.8 & $33 \cdot 8$ & $31 \cdot 1$ & 1.92 & - & - & - \\
\hline Adjusted N intake $(g / d) \S$ & $29 \cdot 3$ & 32.0 & 33.9 & $35 \cdot 8$ & $0 \cdot 14$ & - & 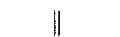 & - \\
\hline Faecal N $(\mathrm{g} / \mathrm{d})$ & 6.0 & 5.9 & 8.8 & 8.9 & 0.83 & $7 \cdot 0$ & $1 \cdot 1 *$ & $0 \cdot 37$ \\
\hline Urinary $N(g / d)$ & $12 \cdot 8$ & $13 \cdot 9$ & $14 \cdot 8$ & $15 \cdot 0$ & 1.03 & - & - & - \\
\hline \multicolumn{9}{|l|}{ Apparently digested $N$} \\
\hline Actual & $26 \cdot 4$ & $27 \cdot 9$ & $25 \cdot 0$ & $22 \cdot 2$ & 1.89 & - & - & - \\
\hline Adjusted§ & $23 \cdot 5$ & $26 \cdot 3$ & $25 \cdot 1$ & $26 \cdot 6$ & 1.01 & - & - & - \\
\hline$N$ retention $(g / d)$ & 13.6 & $14 \cdot 0$ & $10 \cdot 2$ & $7 \cdot 2$ & $1 \cdot 79$ & $12 \cdot 1$ & $-2 \cdot 3^{*}$ & 0.80 \\
\hline $\mathrm{N}$ retention/ $\mathrm{N}$ intake & 0.42 & 0.41 & 0.30 & 0.21 & 0.045 & 0.36 & $-0.07^{*}$ & 0.020 \\
\hline $\begin{array}{l}\mathrm{N} \text { retention/ } \\
\text { apparently digested } \mathrm{N}\end{array}$ & 0.50 & 0.49 & 0.41 & $0 \cdot 28$ & 0.048 & 0.45 & $-0.08^{*}$ & 0.021 \\
\hline Biological value & 0.65 & 0.63 & 0.57 & 0.47 & 0.035 & $0 \cdot 60$ & $-0.06^{* *}$ & 0.016 \\
\hline
\end{tabular}

$* P<0.05, * * P<0.01$.

$\dagger$ For details, see Tables 1 and 2.

$\ddagger$ Regression coefficients with their standard errors are actual values $\times 10^{3}$.

$\S$ Values adjusted for differences in dry matter intake between treatments, with standard error based on $5 \mathrm{df}$.

II A significant quadratic treatment effect but, because of unequal increments in proportion of Pruteen in the diet, the regression equation cannot be calculated since orthogonal polynomials were used in the analysis.

\section{Expt 2. Digestibility and retention of $N, C a$ and $P$}

The results are given in Tables 12 and 13. The DM concentrations in the faeces were very variable (69-261 $\mathrm{g} \mathrm{DM} / \mathrm{kg}$ ), but the mean values for each diet were similar at approximately $136 \mathrm{~g} \mathrm{DM} / \mathrm{kg}$ faeces. DM intake (DMI) decreased significantly with increasing amount of Pruteen in the diets because of reduced palatability and a slightly lower DM concentration in the diet.

Live-weight gain tended to decrease when more Pruteen was included in the diet, but the values adjusted for DMI showed the reverse trend. Live-weight gain and apparent digestibility of DM, organic matter, crude protein, fat and carbohydrate tended to be higher after giving diet P30 than after diet P0 was given. With the exception of carbohydrate digestibility, which was high and similar for all four diets, digestibility decreased markedly with diets P50 and P70. DMI had no significant effect on nutrient digestibility.

Apparent absorption and retention of $\mathrm{Ca}$ and $\mathrm{P}$ decreased significantly with increasing inclusion of Pruteen in the diet. Apparent absorption of ash tended to be greater for diet P30 than when the control diet was given. Adjustment for variation in mean DMI between treatments did not significantly affect the values. $\mathrm{N}$ intake did not differ between diets but was significantly affected by DMI so that, after adjustment, $\mathrm{N}$ intake increased significantly as the amount of Pruteen in the diet was increased. Apparently digested N (ADN) tended to decrease and $\mathrm{N}$ retention significantly decreased as more Pruteen was included. There were slight increases in ADN and $\mathrm{N}$ retention after giving diet $\mathrm{P} 30$ rather than diet $\mathrm{P} 0$, and this effect was enhanced for ADN when the value was adjusted for DMI. The proportion of dietary $\mathrm{N}$ and ADN that was retained and the biological value of the diet decreased with increasing amounts of Pruteen in the diet. 


\section{DISCUSSION}

\section{Apparent digestibility of $N$ fractions, carbohydrate and fat}

In general, the results obtained at the duodenum for Expt 1 agree with those of Sedgman et al. (1985), namely that an increase in the amount of dietary protein derived from Pruteen caused a rise in the outflow of TN and undigested PN from the abomasum, a higher pH for the first $6 \mathrm{~h}$ after feeding and a lower $\mathrm{pH}$ from $6 \mathrm{~h}$ to the end of the collection period.

At the ileum, the increase in TN and undigested PN became even more marked. This could be explained if diets containing Pruteen caused changes to occur in the small intestine similar to those found in the abomasum (Sedgman et al. 1985), i.e. a reduction in the secretion of digestive enzymes and an alteration in the secretion of electrolytes to give less than optimum conditions for digestion. Other non-milk proteins, e.g. soya-bean meal and fishmeal, in milk-substitute diets have been shown to cause a reduction in the secretion of pancreatic juice and digestive enzymes (Ternouth et al. 1975). In addition, the more rapid outflow of undigested protein from the abomasum may result in a faster transit time through the small intestine and thus give less chance for digestion to occur.

The intake at the experimental feed significantly affected the volume of abomasal outflow and the outflow of TN, PN and NPN. Ternouth et al. (1975) also showed that the intake at the experimental feed affected abomasal outflow of TN for diets based on soya-bean and fish protein whereas intake at the penultimate feed affected the TN outflow for those based on milk protein. In the present experiment there was insufficient variation in intake at the penultimate and experimental feeds to divide the results for further analysis.

At the ileum, the flow and composition of the digesta were not significantly affected by intake, except by the penultimate intake of isotope, presumably because the diet had been modified to such an extent that fluctuations in intake would have had to be very large. Apparent digestibility of TN and PN in the small intestine tended to decrease when more Pruteen was included in the diet, but lack of significance may have been caused by duodenal and ileal collections being made on different days. Apparent digestibility of TN and PN from mouth to ileum in Expt 1, and of TN from mouth to anus in Expt 2, decreased significantly with increasing amounts of Pruteen in the diet. If the results of these experiments are combined, an estimate of the apparent disappearance of $\mathrm{N}$ in the large intestine can be obtained. Ileal $\mathrm{N}$ values of $5 \cdot 8,9 \cdot 0,8 \cdot 0$ and $10 \cdot 3 \mathrm{~g} / \mathrm{d}$ from Expt 1 and faecal $\mathrm{N}$ values of $6.0,5.9,8.8$ and $8.9 \mathrm{~g} / \mathrm{d}$ from Expt 2 for treatments P0, P30, P50 and P70 respectively give a mean value of $0.88 \mathrm{~g} \mathrm{~N} / \mathrm{d}$ for disappearance in the large intestine with no clear pattern of an effect of diet. Goodall \& Kay (1965) reported that approximately $1 \mathrm{~g} \mathrm{~N} / \mathrm{d}$ was absorbed from the large intestine of ruminant sheep, which would be approximately of equivalent live weight.

Results from Expt 2 indicated that the highest overall nutrient digestibilities were obtained after giving diet P30. The only variable measured that was common to Expt 1 and Expt 2 was TN. In Expt 1, apparent digestibility of TN from mouth to terminal ileum was highest for the control diet. This discrepancy could possibly be accounted for by a large apparent disappearance of $\mathrm{N}$ from the large intestine when diet P30 rather than P0 was given.

The overall effect of increasing the Pruteen concentration in the diet was a decrease in the digestibility of all nutrients with the exception of carbohydrate. The high digestibility of carbohydrate was expected because lactose was the source in all diets and the efficiency of its digestion is unaffected by the protein source (Gaillard \& Van Weerden, 1976). However, the digestibility of fat is affected by protein source (Raven, 1970; Gibney \& Walker, 1978) and this was significantly reduced as the amount of Pruteen in the diet was increased. 
When $200 \mathrm{~g}$ Pruteen $/ \mathrm{kg}$ diet was used, Van Weerden \& Huisman (1977) found no reduction in protein and fat digestibility. However, their calves were 8 or 16 weeks old, the diets were based on dried skim-milk rather than on whey and the Pruteen diets contained much more protein than did the control diet. In contrast, Roth \& Kirchgessner (1978) and Roth et al. (1979) found a reduced apparent digestibility of DM and N when 120 or $180 \mathrm{~g}$ Pruteen $/ \mathrm{kg}$ diet was used. In the present experiment the diets were formulated to be protein-limiting, but it is possible that energy was limiting rather than protein and this could explain the low biological value observed.

In Expt 1 (a), the flow of $\mathrm{N}$ was further partitioned from PN and NPN into amino acids, nucleic acids and $\mathrm{NH}_{3}$. The amount of Pruteen in the diet did not affect the disappearance of $\mathrm{NH}_{3}$ in the small intestine and, despite the difficulties associated with the measurement of the nucleic acids, their apparent digestibility increased significantly when the diets containing Pruteen were given. Roth \& Kirchgessner (1978) also observed that nucleic acids were almost completely digested by calves given Pruteen-containing diets. Thus it is the reduced digestibility of true protein that causes the overall reduction in digestibility of $\mathbf{N}$.

\section{Apparent absorption of amino acids in the small intestine}

The total outflow of PN at the duodenum and ileum and the total outflow of amino acids at the ileum increased significantly when more Pruteen was included in the diet but the values for total outflow of amino acids were 2.0-3.6 g higher at the duodenum and $0.7-1.3 \mathrm{~g}$ higher at the ileum than those for PN; probably a large proportion of peptides and amino acids were too small to be precipitated by the trichloracetic acid used in the determination of PN.

As with PN, the apparent digestibility of the individual amino acids also decreased with increasing Pruteen inclusion in the diet, which suggests that some of the bacterial protein is undigested by the enzymes. In the ruminant calf, microbial protein produced during fermentation in the rumen forms a large proportion of the protein entering the duodenum. The estimates of the apparent digestibility of this microbial protein in the small intestine of the ruminant animal, e.g. 0.64 (Smith et al. 1975); 0.86 (Tas et al. 1977); 0.70 (Walker et al. 1979); 0.81 (Storm et al. 1983) are similar to that of the protein from Pruteen in the preruminant calf and are much lower than the value of 0.91 for milk protein (Table 5).

The outflow and disappearance of an individual amino acid appeared to be closely related to its proportion in the diet. As the amount of Pruteen in the diet increased, the relative proportion of each amino acid to the total became progressively more dissimilar from that of milk protein. Artificial amino acid imbalances are known to have a detrimental effect on growth (Rogers, 1976) and maximum biological value of a diet will only be achieved if the essential amino acids from the digested protein are in the correct proportions for the tissue requirements.

\section{Absorption of essential amino acids in relation to requirements}

In Table 14 the daily intake of essential amino acids is compared with the estimated requirement of the preruminant calf of $50-58 \mathrm{~kg}$ live weight, gaining weight at approximately $0.25 \mathrm{~kg} / \mathrm{d}$ (Williams \& Hewitt, 1979). The requirements were estimated by Williams \& Hewitt (1979) from responses to lysine supplementation of the diet. Requirements of other essential amino acids were calculated from the ratio, lysine:essential amino acids in the carcass. The results given in Table 14 indicate that only arginine is limiting. Since the milk-protein diet $\mathrm{P} 0$ has the largest deficit, some arginine must be synthesized by the calf to meet its requirements (Williams \& Hewitt, 1979).

Comparison of the apparently absorbed essential amino acids with requirement suggests that there is a deficiency of arginine and cystine for all diets and, additionally, a deficiency 
Table 14. Comparison of dietary intake and apparent absorption of essential amino acids from the small intestine of preruminant calves given milk-substitute diets containing $0(P 0), 300 \mathrm{~g}$ (P30), $500 \mathrm{~g}(P 50)$ and $700 \mathrm{~g}($ P70) bacterial protein (Pruteen; ICI Ltd) $/ \mathrm{kg}$ total protein in the diet, with the estimated daily requirement of essential amino acids (Williams \& Hewitt, 1979)

\begin{tabular}{|c|c|c|c|c|c|c|c|c|c|}
\hline \multirow[t]{2}{*}{$\operatorname{Diet}^{*} \ldots$} & \multirow[b]{2}{*}{$\begin{array}{l}\text { Dietary } \\
\text { requirement }\end{array}$} & \multicolumn{2}{|r|}{ P0 } & \multicolumn{2}{|r|}{ P30 } & \multicolumn{2}{|c|}{ P50 } & \multicolumn{2}{|c|}{ P70 } \\
\hline & & Intake & $\begin{array}{l}\text { Apparently } \\
\text { absorbed }\end{array}$ & Intake & $\begin{array}{l}\text { Apparently } \\
\text { absorbed }\end{array}$ & Intake & $\begin{array}{l}\text { Apparently } \\
\text { absorbed }\end{array}$ & Intake & $\begin{array}{c}\text { Apparently } \\
\text { absorbed }\end{array}$ \\
\hline Threonine & $4 \cdot 9$ & 9.9 & 6.9 & $9 \cdot 2$ & $7 \cdot 7$ & $10 \cdot 0$ & $7 \cdot 4$ & $11 \cdot 0$ & $7 \cdot 4$ \\
\hline Cystine & 1.6 & $2 \cdot 2$ & $1.4 \dagger$ & 1.9 & $1 \cdot 2 \dagger$ & $2 \cdot 0$ & $1 \cdot 1 \dagger$ & $3 \cdot 5$ & $1 \cdot 0 \dagger$ \\
\hline Valine & $4 \cdot 8$ & $9 \cdot 3$ & $7 \cdot 7$ & $10 \cdot 7$ & $7 \cdot 8$ & $8 \cdot 8$ & $7 \cdot 6$ & 8.8 & $6 \cdot 9$ \\
\hline Methionine & $2 \cdot 1$ & $4 \cdot 8$ & $3 \cdot 3$ & $4 \cdot 6$ & $3 \cdot 4$ & $4 \cdot 5$ & $3 \cdot 3$ & $4 \cdot 2$ & $3 \cdot 0$ \\
\hline Isoleucine & $3 \cdot 4$ & $8 \cdot 0$ & $7 \cdot 1$ & 9.0 & $7 \cdot 2$ & $7 \cdot 9$ & $7 \cdot 2$ & $7 \cdot 5$ & 6.6 \\
\hline Leucine & 8.4 & $19 \cdot 0$ & $15 \cdot 4$ & $18 \cdot 3$ & $15 \cdot 7$ & $17 \cdot 2$ & $14 \cdot 0$ & $15 \cdot 1$ & 12.9 \\
\hline Tyrosine & 3.0 & $7 \cdot 8$ & 6.5 & $7 \cdot 0$ & 6.0 & 6.5 & $5 \cdot 0$ & $6 \cdot 2$ & $4 \cdot 1$ \\
\hline Phenylalanine & $4 \cdot 4$ & $8 \cdot 4$ & $7 \cdot 1$ & $8 \cdot 0$ & 6.9 & $7 \cdot 5$ & $6 \cdot 0$ & $7 \cdot 4$ & $5 \cdot 2$ \\
\hline Histidine & $3 \cdot 0$ & $4 \cdot 2$ & $3 \cdot 7$ & $4 \cdot 5$ & $3 \cdot 6$ & 3.7 & $3 \cdot 1$ & 3.5 & $2 \cdot 5 \dagger$ \\
\hline Lysine & 7.8 & $14 \cdot 0$ & 11.9 & $13 \cdot 3$ & $12 \cdot 0$ & $13 \cdot 0$ & 10.9 & $13 \cdot 3$ & $10 \cdot 2$ \\
\hline Arginine & $8 \cdot 5$ & $5 \cdot 4 \dagger$ & $4 \cdot 7+$ & $7 \cdot 2+$ & $5 \cdot 6+$ & $7 \cdot 4 \dagger$ & $5 \cdot 7 \dagger$ & $8.0 \dagger$ & $6.5 t$ \\
\hline $\begin{array}{l}\text { Cystine + } \\
\text { methionine }\end{array}$ & $3 \cdot 7$ & $7 \cdot 0$ & 4.7 & $6 \cdot 6$ & $4 \cdot 7$ & $6 \cdot 5$ & $4 \cdot 4$ & $7 \cdot 7$ & 3.9 \\
\hline
\end{tabular}

* For details, see Tables 1 and 2

† Apparent deficiency of amino acid.

of histidine for diet P70. However, if the amounts of absorbed cystine and methionine are added together, there is no apparent deficiency of S-containing amino acids. If it is assumed that the calf can synthesize arginine, the only deficiency is of histidine in diet P70 and possibly also in P50 where supply is only slightly above requirement.

The apparent digestibility and the amount of cystine absorbed in the small intestine or from mouth to ileum was lower than for any other amino acid. A low apparent digestibility but high true digestibility of cystine in the small intestine has been reported by Armstrong et al. (1977). Moreover, the results of an experiment using ${ }^{35} \mathrm{~S}$-labelled cystine by Walker et al. (1979) suggest that there is an endogenous secretion into the small intestine that is rich in cystine and poorly reabsorbed.

\section{True digestibility of ${ }^{3} \mathrm{H}$-labelled milk protein and ${ }^{35} \mathrm{~S}$-labelled bacterial protein}

The concentration of ${ }^{3} \mathrm{H}$ in the duodenal digesta for the first $3 \mathrm{~h}$ after feeding was higher as the amount of Pruteen in the diet increased, presumably due to a decreasing ability of the diet to clot in the abomasum. However, overall the dietary effect was not significant and the recovery of ${ }^{3} \mathrm{H}$ during $12 \mathrm{~h}$ was only slightly higher for the diets containing Pruteen. Ternouth et al. (1975), also using ' ${ }^{3} \mathrm{H}$-labelled goats' milk, found that greater amounts of ${ }^{3} \mathrm{H}$ were recovered in the duodenal digesta in $12 \mathrm{~h}$ after giving fishmeal $(0 \cdot 71)$ and soya-bean meal $(0.75)$ rather than milk protein $(0.53)$. In the present experiment, the recoveries were $0.64,0.72,0.84$ and 0.82 for diets P0, P30, P50 and P70 respectively. The higher recovery for the milk-protein diet in the present experiment may have arisen from the inclusion of $298 \mathrm{~g}$ whey $/ \mathrm{kg}$ in the diet rather than only skim-milk and fat in the milk diet of Ternouth et al. (1975); thus a less firm clot may have been formed in the present experiment. Since the values for true digestibility of ${ }^{3} \mathrm{H}$ in the small intestine or between the mouth and ileum 
were high and did not differ between diets, it appears that the digestibility of milk protein was unaffected by the presence of increasing amounts of bacterial protein.

The true digestibility of ${ }^{35} \mathrm{~S}$ in the small intestine was considerably lower than that of ${ }^{3} \mathrm{H}$, but it tended to increase with a greater amount of Pruteen in the diet. Thus even when Pruteen was included in very small amounts in diet P0 to enable ${ }^{35} \mathrm{~S}$ inclusion to be tested, and was unlikely to affect digestive enzyme secretion, it was poorly digested. When measured from mouth to terminal ileum, the increase in digestibility with greater amounts of Pruteen in the diet was significant. As the amount of Pruteen was increased, it is probable that the diets became more protein-limiting and the increase in digestibility could possibly be explained by an increase in efficiency of enzymic digestion. However the ${ }^{3} \mathrm{H}$ labelled only the lysine in milk and the ${ }^{35} \mathrm{~S}$ only the cystine and methionine in Pruteen. The isotopes will thus indicate the behaviour of the total protein only if the amino acids are evenly distributed and if there is no preferential cleavage and release of these amino acids.

\section{Estimation of endogenous protein secretion}

The isotope results were used to obtain estimates of endogenous protein secretion and were based on the following assumptions:

(1) The digestibility of ${ }^{3} \mathrm{H}$ gives a measure of true lysine digestibility.

(2) Lysine outflow $-\left({ }^{3} \mathrm{H}\right.$ recovery $\times$ lysine intake $)=$ endogenous lysine.

$$
\frac{\text { PN outflow }}{\text { Lysine outflow }}=\frac{\text { Endogenous PN }(\mathrm{EPN})}{\text { Endogenous lysine }} \text {, }
$$

where ${ }^{3} \mathrm{H}$ recovery is $\left({ }^{3} \mathrm{H}\right.$ outflow at the ileum) $/\left(\right.$ dietary $\left.{ }^{3} \mathrm{H}\right)$, lysine intake is equal to dietary lysine, lysine outflow is equal to ileal outflow of lysine, PN outflow is equal to ileal outflow of PN and EPN is equal to EPN secreted between the mouth and terminal ileum. The calculations for ${ }^{35} \mathrm{~S}$ were similar, but with lysine replaced by cystine + methionine.

As the two sets of calculations gave different values for EPN, it is clear that for diets containing Pruteen the method cannot be used, since it assumes that the absorption of all lysine or all cystine and methionine in the diet is the same as for $\left[{ }^{3} \mathrm{H}\right] l y s i n e$ and $\left[{ }^{35} \mathrm{~S}\right]$ cystine + methionine respectively. It is known, however, that the absorption of both amino acids declined with increasing concentration of Pruteen in the diet.

The value of EPN for diet P0 based on endogenous lysine secretion gave values of 1.3 , $0 \cdot 10$ and $0.18 \mathrm{~g}$ protein- $\mathrm{N} / 12 \mathrm{~h}$ for mouth to duodenum, duodenum to ileum and mouth to ileum. The amount of EPN is the amount of PN that is unlabelled, some of which may have been left from the previous unlabelled meal, which at the duodenum may be quite considerable; thus the EPN value of $1.3 \mathrm{~g}$ between mouth and duodenum is likely to be an overestimate. The values of 0.08 (i.e. $0 \cdot 18-0 \cdot 10) \mathrm{g} \mathrm{EPN} / 12 \mathrm{~h}$ secreted between the mouth and duodenum and $0.1 \mathrm{~g} \mathrm{EPN} / 12 \mathrm{~h}$ secreted into the small intestine are low and suggest that EPN may be readily absorbed from the small intestine. Roy et al. (1977) estimated that in the preruminant calf, metabolic faecal $N$ (MFN), i.e. the unabsorbed secretions of $\mathrm{N}$-containing compounds in the whole alimentary tract, is $1.9 \mathrm{~g} \mathrm{~N} / \mathrm{kg} \mathrm{DMI}$. Using this value and the DMI for diet P0, the mean MFN would be $0.85 \mathrm{~g} / 12 \mathrm{~h}$, i.e. $1.7 \mathrm{~g} \mathrm{~N} / \mathrm{d}$, whilst the value for EPN from mouth to ileum in the present experiment is $0.36 \mathrm{~g} / \mathrm{d}$. However, MFN includes nucleic acids and ammonia and also unabsorbed $\mathrm{N}$ produced in the large intestines.

\section{Estimation of the efficiency of utilization of apparently absorbed protein for tissue synthesis and to cover obligatory loss}

This efficiency can be calculated using either the absorption of total amino acids or the absorption of (TN less nucleic acid-N less $\mathrm{NH}_{3}-\mathrm{N}$ ), as the denominator in the equation: 


$$
\text { Efficiency of utilization }=\frac{\mathrm{N} \text { retention }+\mathrm{EUN}+\mathrm{N} \text { loss in hair and scurf }}{\begin{array}{c}
\text { Amino acid- } \mathrm{N} \text { or }\left(\mathrm{TN}-\text { nucleic acid- } \mathrm{N}-\mathrm{NH}_{3}-\mathrm{N}\right) \\
\text { apparently absorbed in the small intestine }
\end{array}},
$$

where EUN (endogenous urinary-N) is a measure of the basal and inevitable loss of $\mathrm{N}$ from the body estimated as either $175 \mathrm{mg} / \mathrm{kg}$ live weight $\mathrm{t}^{075}$ (Roy et al. 1977) or $5.9206 \log _{10}$ live weight -6.76 (Agricultural Research Council, 1980). Both calculations gave similar values, which were corrected $(E U N \times 0.76)$ for the proportion of EUN that was not derived from amino acids; the correction was based on the partition of $\mathrm{N}$ in urine given by Hutchinson \& Morris (1936), Blaxter \& Wood (1951) and Walker \& Faichney (1964). N loss in hair and scurf was calculated from $0 \cdot 18$ live weight ${ }^{0.75}$ (Agricultural Research Council, 1980).

Since there were slight differences in $\mathrm{N}$ intake between experiments, the values were adjusted by covariance to the mean $\mathrm{N}$ intake. The values for adjusted efficiency were 0.90 , $0.80,0.73$ and 0.53 when the denominator was amino acid absorption and $0.69,0.69,0.58$ and 0.39 when the denominator was in terms of $\left(\mathrm{TN}-\right.$ nucleic acid- $\left.\mathrm{N}-\mathrm{NH}_{3}-\mathrm{N}\right)$ absorption for diets P0, P30, P50 and P70 respectively. Mean values of $0.80,0.75,0.66$ and 0.47 for P0, P30, P50 and P70 respectively would appear to be the best estimates of efficiency. If amino acid absorption is used, efficiency is probably overestimated because amino acid disappearance is underestimated since not all amino acids were measured and there is an inevitable loss during the analytical procedure. The use of $\mathrm{N}$ absorption gives an underestimate since it assumes that all the $\mathrm{N}$ absorbed from the small intestine that is not nucleic acid- $\mathrm{N}$ or $\mathrm{NH}_{3}-\mathrm{N}$ is amino acid-N. However, galactosamine and glucosamine were detected in appreciable quantities. In addition, nucleic acid absorption is artificially low because of the low values of RNA obtained at the duodenum. For these reasons (TN less nucleic acid- $\mathrm{N}$ less $\mathrm{NH}_{3}-\mathrm{N}$ ) absorption in the small intestine will be greater than that for amino acids.

The reduced efficiency with increasing concentration of Pruteen in the diet presumably arises from an increasing imbalance of amino acids in relation to requirement or possibly from energy becoming more limiting in the diets. The value of 0.80 for diet P0 is the same as that suggested in Agricultural Research Council (1980) for the efficiency of utilization of ADN in the preruminant calf.

\section{Estimation of the efficiency of utilization of apparently absorbed individual amino acids for tissue synthesis and to cover obligatory loss}

Efficiency of utilization of individual amino acids absorbed from the small intestine may be calculated if it is assumed that the proportion of an individual amino acid to TN content is the same for $\mathrm{N}$ retention, EUN and $\mathrm{N}$ in the whole empty body. Thus

$$
\text { Daily lysine retention }=\text { Daily } N \text { retention } \times \frac{\text { Lysine } N \text { in whole empty body }}{T N \text { in whole empty body }} \text {, }
$$

and

$$
\text { Lysine in EUN }=E U N \times \frac{\text { Lysine } N \text { in whole empty body }}{\text { TN in whole empty body }} .
$$

The amino acid composition of the whole empty body of the calf was obtained from Williams (1978) and the amino acid content of the $\mathrm{N}$ lost in hair and scurf from a partial analysis given by Rothman (1965) for histidine, lysine, arginine, cystine, tyrosine and phenylalanine. The efficiencies of utilization are given in Table 15; the efficiencies will be slightly underestimated for those amino acids not determined by Rothman (1965).

Values for cystine were greater than unity presumably because of the low apparent 
Table 15. Estimated efficiencies of utilization of apparently absorbed essential amino acids for tissue synthesis and obligatory losses in urine and hair and scurf in preruminant calves given milk-substitute diets containing 0 (P0), $300 \mathrm{~g}$ (P30), $500 \mathrm{~g}$ (P50) and $700 \mathrm{~g}$ (P70) bacterial protein (Pruteen; ICI Ltd) $/ \mathrm{kg}$ total protein in the diet

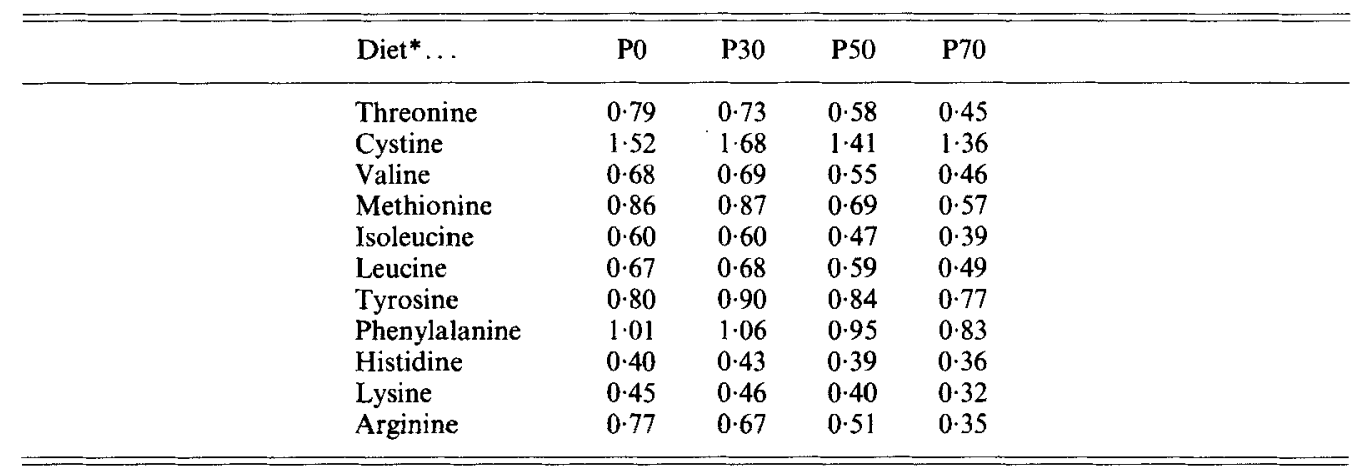

* For details, see Tables 1 and 2.

absorption in the small intestine, thought to be associated with the net secretion of a cystine-rich protein into the small intestine. With the exception of arginine and threonine, efficiencies of utilization tended to be higher for diet P30, probably as a result of the higher $\mathrm{N}$ retention for calves given this diet. There was clearly a decrease in efficiency of utilization of individual amino acids with inclusion of larger amounts of Pruteen in the diet.

Since the efficiency values are based on assumptions and there is little information in the literature for the preruminant calf, they should be viewed with caution. In particular, the values obtained for lysine and histidine were rather low even for the milk diet, P0. Buttery \& Annison (1976) reviewed the available information on the efficiency of utilization of amino acids and also found that the retention of absorbed essential amino acids was relatively inefficient in rats, pigs and poultry. They concluded that this could be attributed to the continuous turnover of tissue protein and poor re-utilization of the amino acids together with possible imbalance in the amino acid supply.

The results from these experiments and those reported previously indicate that inclusion of more than $100 \mathrm{~g}$ Pruteen $/ \mathrm{kg}$ dry diet in milk substitutes (approximately $300 \mathrm{~g}$ Pruteen protein $/ \mathrm{kg}$ total protein in the diet) will adversely affect nutrient digestibility and growth of the calf. This reduction in performance was associated with reduced abomasal enzyme secretion and a higher abomasal $\mathrm{pH}$, giving less than optimum conditions for proteolysis; resistance of Pruteen to attack by the abomasal proteases (Sedgman, 1980); faster outflow of undigested protein from the abomasum associated with lack of clotting, resulting in less time for proteolysis to occur; reduced digestion in the small intestines of total PN and individual amino acids; and greatly reduced efficiency of utilization of apparently absorbed amino acids.

The authors are grateful to the staff of the Feeding and Metabolism Department calf unit for the care of the experimental animals; Dr $\mathbf{H}$. Buttle for performing the surgical operations; Mr E. Florence and the staff of the Analytical Chemistry Section for help with the chemical analyses; and ICI Ltd, Billingham for the supply of Pruteen and of ${ }^{35}$ S-labelled Pruteen. 


\section{REFERENCES}

Agricultural Research Council (1980). The Nutrient Requirements of Ruminant Livestock. Slough: Commonwealth Agricultural Bureaux.

Armstrong, D. G., Savage, G. P. \& Harrison, D. G. (1977). In Proceedings 2nd International Symposium Protein Metabolism and Nutrition, EAAP Publication no. 22, pp. 55-60 [S. Tamminga, editor]. Wageningen: Centre for Agricultural Publishing and Documentation.

Ash, R. W. (1962). Animal Production 4, 309-312.

Blaxter, K. L. \& Wood, W. A. (1951). British Journal of Nutrition 5, 11-25.

Buttery, P. J. \& Annison, E. F. (1976). Reviews in Rural Science 2, 111-122.

Gaillard, B. D. E. \& Van Weerden, E. J. (1976). British Journal of Nutrition 36, 471-478.

Gibney, M. J. \& Walker, D. M. (1978). Australian Journal of Agricultural Research 29, $133-144$.

Goodall, E. D. \& Kay, R. N. B. (1965). Journal of Physiology, London 176, 12-23.

Hutchinson, J. C. D. \& Morris, S. (1936). Biochemical Journal 30, 1682-1694.

McAllan, A. B. \& Smith, R. H. (1969). British Journal of Nutrition 23, 671-682.

Moore, S. (1963). Journal of Biological Chemistry 238, 235-237.

Raven, A. M. (1970). Journal of the Science of Food and Agriculture 21, 352-359.

Rogers, Q. R. (1976). In Protein Metabolism and Nutrition, EAAP Publication no. 16 pp. 279-301. [D. J. A. Cole, editor] London: Butterworths.

Roth, F. X. \& Kirchgessner, M. (1978). Zeitschrift für Tierphysiologie, Tierernährung und Futtermittelkunde 41, 29-39.

Roth, F. X., Kirchgessner, M. \& Muller, H. L. (1979). Zeitschrift für Tierphysiologie, Tierernährung und Futtermittelkunde 41, 313-325.

Rothman, S. (1965). Physiology and Biochemistry of the Skin, p. 352. Chicago: University of Chicago Press.

Roy, J. H. B., Stobo, I. J. F., Shotton, S. M., Ganderton, P. \& Gillies, C. M. (1977). British Journal of Nutrition 38, $167-187$.

Sedgman, C. A. (1980). Studies on the digestion, absorption and utilisation of single cell protein by the preruminant calf. PhD Thesis, University of Reading.

Sedgman, C. A., Roy, J. H. B. \& Thomas, J. (1985). British Journal of Nutrition 53, 673-689.

Smith, R. H., Salter, D. N., Sutton, J. D. \& McAllan, A. B. (1975). Tracer Studies of Non-protein N for Ruminants, pp. 81-93. Vienna: International Atomic Energy Agency.

Spackman, D. H., Stein, W. H. \& Moore, S. (1958). Analytical Chemistry 30, 1190-1206.

Stobo, I. J. F., Roy, J. H. B. \& Ganderton, P. (1979). Journal of Agricultural Science, Cambridge 93, 95-110.

Storm, E., Ørskov, E. R. \& Smart, R. (1983). British Journal of Nutrition 50, 471-478.

Tas, M. V., Axford, R. F. E. \& Evans, R. A. (1977). Proceedings of the Nutrition Society 36, 76 A.

Technicon Instruments Co. Ltd (1969). Technicon Methodology Sheet 18-69W. Basingstoke: Technicon Instruments Co. Ltd.

Ternouth, J. H., Roy, J. H. B., Stobo, I. J. F., Ganderton, P., Gillies, C. M. \& Shotton, S. M. (1974). British Journal of Nutrition 32, 37-45.

Ternouth, J. H., Roy, J. H. B., Thompson, S. Y., Toothill, J., Gillies, C. M. \& Edwards-Webb, J. D. (1975). British Journal of Nutrition 33, 181-196.

Van Weerden, E. J. \& Huisman, J. (1977). Animal Feed Science and Technology 2, 377-383.

Walker, A. C. U., Weekes, T. E. C. \& Armstrong, D. G. (1979). Protein Metabolism in the Ruminant, pp. 2.1-2.8. London: Agricultural Research Council.

Walker, D. M. \& Faichney, A. J. (1964). British Journal of Nutrition 18, 201-207.

Williams, A. P. (1978). Journal of Agricultural Science, Cambridge 90, 617-624.

Williams, A. P. \& Hewitt, D. (1979). British Journal of Nutrition 41, 311-319.

Yates, F. (1933). Empire Journal of Experimental Agriculture 1, 129-142. 